\title{
Desindustrialização regional no Brasil
}

\author{
Regional deindustrialization in Brazil
}

\author{
Fagner Diego Spindola Correia Monteiro \\ Instituto Federal de Pernambuco \\ João Policarpo Rodrigues Lima \\ Universidade Federal de Pernambuco
}

\begin{abstract}
This work aims at analyzing, for an unprecedented perspective, possible evidences of deindustrialization in the Brazilian economy. For that, it analyzes both regional and state data for the period 1985-2010, using indicators of deindustrialization already established. In addition, regional differences in the relation VTI / VBPI are analyzed and discussed considering winners and losers in terms of sectors and regions, presenting also possible reasons for the divergent behavior of the process by region. Finally, it estimates a parametric model regressing the participation of regional manufacturing industry in the region's GDP and regional per capita income. The results suggest that, at regional level, the Southeast, South and Northeast regions accumulate evidence of deindustrialization, while the other two regions follow an inverse pattern. Besides that, it seems that the Brazilian deindustrialization is in progress together with a process of (regional) spatial decentralization of industrial production and this deindustrialization process affects differently the regions.
\end{abstract}

\section{Keywords}

deindustrialization; regional economy; manufacturing industry.

JEL Codes L16; R12; L60.

\section{Resumo}

Este trabalho tem como objetivo analisar, por uma perspectiva inédita, possiveis indícios de desindustrialização na economia brasileira. Para tanto, analisamos dados regionais e estaduais referentes ao periodo de 1985 a 2010, utilizando indicadores de desindustrialização já consagrados. Adicionalmente, são analisadas diferenças regionais da relação VTI/NBPI e discute-se sobre ganhadores e perdedores do ponto de vista setorial e regional, ponderando-se razões para o comportamento divergente do processo por região. Por fim, estima-se um modelo paramétrico regredindo participação da indústria de transformação regional no PIB da região e renda per capita regional. Conclui-se que, em nivel regional, as regiões Sudeste, Sul e Nordeste acumulam indícios de desindustrialização, enquanto as demais regiões seguem padrão inverso, levando a crer que a desindustrialização brasileira é, em parte, também uma descentralização espacial (regional) da produção industrial e que o processo de desindustrialização brasileiro difere entre as regiões acometidas pelo processo.

\section{Palavras-chave}

desindustrialização; economia regional; indústria de transformação.

Códigos JEL L16; R12; L60. 


\section{Introdução}

A acalorada discussão sobre a hipótese de desindustrialização no Brasil resiste ao tempo, seja pela aparente necessidade que a academia nacional tem em comparar processos nacionais com aqueles que acometem os países desenvolvidos, e com isso obter subsídios para explicar o subdesenvolvimento brasileiro, seja pela falta de uma melhor concordância sobre o que de fato caracteriza o fenômeno da desindustrialização.

Os avanços no sentido de confirmar ou refutar a hipótese de desindustrialização para o Brasil são muitos. Os frutos da resiliente discussão acadêmica entre autores de perfil "ortodoxo" e os de perfil "novo-desenvolvimentista" parecem gerar resultados que, em parte, surgem como consequência de suas crenças. Segundo Curado (2013), o debate do pensamento econômico brasileiro é profundamente marcado pelos diferentes pontos de partida teóricos e metodológicos adotados. Entretanto, alguns trabalhos têm conseguido extrapolar a bipolaridade da discussão e chamar atenção para questões relevantes sobre o tema, independentemente de correntes teóricas, como será discutido mais adiante.

Em se tratando de um tema ainda não esgotado na literatura, a hipótese sobre o processo de desindustrialização, dita prematura, em países em desenvolvimento, mantém algumas perguntas a serem respondidas. Entre elas está a necessidade de saber se a perda de importância da Indústria de Transformação, tanto no valor adicionado do produto interno bruto (PIB) quanto no emprego, é padrão nas diversas regiões do país. Dessa forma, este artigo propõe-se a alavancar a discussão para um nível pouco explorado na literatura: a desagregação da hipótese de "desindustrialização" do Brasil com enfoque regional, na perspectiva de melhor entender esse suposto processo.

Assim, este trabalho está estruturado em adicionalmente mais três seções. A segunda discorre sobre as principais discussões encontradas na literatura e os avanços mais recentes. A seção seguinte discutirá a evolução do padrão regional industrial brasileiro, desde a segunda metade da década de 1980 até os dias atuais. Por fim, são tecidas as principais conclusões. 


\section{Referencial teórico}

Ao abordar estudos que tratam do objeto desindustrialização, questiona-se se este é um problema econômico real ou, simplesmente, um estágio inerente ao capitalismo. À luz da teoria econômica vigente, Rowthorn e Ramaswany concordam com a visão de outros autores (Balmol, 1967; Fuchs, 1968; Rowthorn; Wells, 1987; Baumol; Blackman; Wolff, 1989; apud Rowthorn; Ramaswany, 1999, p. 19) afirmando que "a desindustrialização em economias avançadas não é necessariamente um fenômeno indesejável, mas essencialmente uma consequência natural do dinamismo exibido por esses países" (1999, p.18-19, tradução nossa). Neste sentido, concluem que a desindustrialização em países em estado avançado de desenvolvimento econômico resulta de interações nas mudanças no padrão de preferências entre manufaturas e serviços, do rápido crescimento da produtividade no setor industrial comparado ao setor de serviços, e da diminuição de preço das manufaturas associada a esse processo. Além disso, consideraram que a concorrência enfrentada por esses países, advinda das trocas com os países em desenvolvimento, tem como principal efeito a elevação da produtividade nas economias avançadas, e teve um pequeno efeito na quantidade de produto final dessas economias. A diminuição da taxa de investimento frente ao PIB aparece como outro possível fator explicativo causador da desindustrialização. ${ }^{1}$

O conceito mais recentemente proposto sobre o que caracteriza a desindustrialização é encontrado em Tregenna (2009). Segundo a autora, a desindustrialização é uma situação na qual tanto o emprego industrial quanto o valor adicionado da indústria se reduzem como proporção do emprego total e do PIB, respectivamente. Esse é o conceito mais aceito pela literatura, sendo encontrado em diversos outros estudos aplicados ao Brasil (Oreiro; Feijó, 2010; Cruz; Santos, 2011; Wasques, 2012; Wasques; Trintin, 2012).

Além de discutir a existência do processo de desindustrialização, consideráveis progressos foram feitos no sentido de tentar responder quais aspectos estão correlacionados com a redução da participação da manufatura no valor adicionado (VA), observado no Brasil. Marconi e Rocha (2012) encontram uma correlação significativa entre a apreciação da taxa

1 A participação de produtos manufaturados no PIB tende a ser impulsionada por elevadas taxas de incremento da formação bruta de capital fixo. 
de câmbio e o valor adicionado pela indústria manufatureira, em que uma apreciada taxa de câmbio tem provavelmente influenciado a redução da participação industrial no VA. Um resultado adicional, testado no referido estudo, é que o uso de insumos importados exerce efeitos negativos e estatisticamente significantes sobre o valor agregado das manufaturas no país. A persistência deste processo, supondo a manutenção dos bens produzidos para consumo interno e externo, poderá se traduzir em efeitos preponderantemente negativos, decorrentes da especialização vertical na produção de bens exportáveis. ${ }^{2}$

Sonáglio et al. (2010) seguem semelhante linha de argumentação acerca da possibilidade de influência da taxa de câmbio sobre uma possível perda de competitividade dos produtos exportáveis. A partir de análise econométrica com dados que abrangem o período entre 1996 e 2008, observam que houve modificação na pauta de exportações, o que pode ter sido influenciado pelo cenário internacional e pelo movimento da taxa real de câmbio. Tal trabalho sugere que a elevada taxa de juros da economia e a taxa de câmbio apreciada têm contribuído para uma reprimarização da pauta de exportação.

Outra hipótese levantada sobre a possível desindustrialização brasileira é a de que a abertura comercial, associada às reformas liberalizantes na década de 1990, expôs a indústria nacional à competição internacional excessiva, sem que essa estivesse em condições de fazer frente ao novo cenário. Ou seja, o setor industrial não era maduro o suficiente para a existência de vantagens competitivas. No entanto, Feijó et al. (2005) e Nassif (2008) argumentam que a diminuição da participação da indústria no PIB tivera início em período anterior à abertura econômica, ainda na década de 1980, devido aos problemas gerados pelas crises inflacionárias, tendo se prolongado por quase toda a década de 1990, com uma leve retomada do crescimento em 1999 a partir da liberalização cambial e da sua elevada desvalorização registrada nos anos seguintes. Essa conclusão é parcialmente contestada em Wasques e Trintin, ao afirmarem que "as mudanças ocorridas na indústria de transformação brasileira ao longo do período 1990-1999 não devem ser caracterizadas como um processo inequívoco de desindustrialização"

2 Existem efeitos positivos e negativos na especialização vertical, entretanto, dada a estrutura de produção de bens brasileira, os efeitos negativos tenderiam a preponderar sobre os positivos. Na Coreia do Sul, preponderariam os efeitos positivos. Uma avaliação mais detalhada dos efeitos gerados pela especialização vertical pode ser visto em Marconi e Rocha (2012, p. 861). 
(2012, p.1). Os autores argumentam que houve uma reestruturação do setor industrial no período, levando a indústria nacional a um patamar mais produtivo, eficiente e mundializado.

No contexto do tema desindustrialização no Brasil, cabe fazer uma breve classificação sobre o que defendem os "economistas ortodoxos" e quais as ideias dos "novos-desenvolvimentistas". De acordo com Oreiro e Feijó, os economistas ortodoxos, tomando como base o período posterior à mudança cambial:

Insistem na tese de que, para esse periodo, não existem dados que comprovem a continuidade do processo de desindustrialização da economia brasileira. Pelo contrário, as mudanças macroeconômicas pelas quais o Brasil passou pós-1999, com a implementação do tripé metas de inflação-superávit primário-câmbio flutuante, teria permitido um crescimento bastante robusto da produção industrial, eliminando assim o fantasma da desindustrialização. (2010, p. 227).

Adicionalmente, os economistas de perfil ortodoxo discordam da possibilidade da existência de "nova doença holandesa" no Brasil, com adeptos inclusive entre os novos-desenvolvimentistas, sob o argumento de que não se constatou "realocação generalizada de fatores produtivos para os segmentos que constituem o grupo de indústrias com tecnologias baseadas em recursos naturais" (Nassif, 2008, p. 93,), como também "não se configurou um retorno vigoroso a um padrão de especialização exportadora em produtos intensivos em recursos naturais ou em trabalho" (Nassif, 2008, p. 94). Para isso, o autor analisou a participação conjunta dos produtos primários, dos manufaturados intensivos em recursos naturais e dos manufaturados de baixa tecnologia nas exportações brasileiras. Os dados mostraram um decréscimo de $72 \%$ para $67 \%$ entre 1989 e 2005.

Em contrapartida, para os economistas novos-desenvolvimentistas, a existência da desindustrialização é evidente, assim, o objeto de discussão dos trabalhos heterodoxos são mais voltados para o debate das causas desse processo. Segundo Oreiro e Feijó (2010, p. 229), "trata-se de debater se esse fenômeno é um resultado natural do estágio de desenvolvimento da economia brasileira ou se é a consequência das políticas macroeconômicas adotadas nos últimos 20 anos". Ainda segundo Oreiro e Feijó (2010, p. 231):

Estudos recentes a respeito da composição do saldo comercial brasileiro e da composição do valor adicionado da indústria brasileira mostram sinais inquietantes da ocorrência de "doença holandesa", ou seja, de desindustrialização causada pela apreciação da taxa real de câmbio que resulta da valorização dos preços das commodities e dos recursos naturais no mercado internacional. 
Em suma, percebe-se a existência de um padrão de discussão entre "ortodoxos" e "heterodoxos" com a enfática produção de conclusões antagônicas, aparentemente por se tratar de trabalhos que são fundamentados em teorias e metodologias diferentes. Essa espécie de discussão parece ter origem no âmago da ciência econômica e tem motivado cientistas sociais brasileiros em pesquisas, algumas vezes apenas contra factuais, mas sem grandes motivações na resolução do problema em si. Uma boa revisão dos elementos motivadores dos debates sobre a industrialização no Brasil pode ser encontrada em Curado (2013), que considera que a controvérsia atual sobre a desindustrialização preserva "semelhanças" com os debates do passado sobre o processo de industrialização nacional, sem vencedores ou vencidos. Nesses termos, muito ainda há que se explorar sobre o tema.

Abordagens alternativas ${ }^{3}$ têm sido produzidas fazendo uso de diversos outros indicadores, no entanto, nenhuma delas parece responder definitivamente aos questionamentos originais da discussão sobre a existência ou não da desindustrialização no Brasil. Isso não significa que essas abordagens sejam de pouca significância ou que não se tenha caminhado no sentido de melhor entender o processo. São avanços necessários, tais quais os deste artigo que se propõe a dar uma contribuição para o melhor esclarecimento do tema.

Dois trabalhos que chamam particular atenção são os de Squeff (2012) e Martins e Lima (2015), por realizarem análises com dados e argumentações singulares. O texto para discussão de Squeff (2012) discute a hipótese de desindustrialização brasileira a partir de indicadores não encontrados usualmente na literatura sobre o tema, entre os quais, indicadores relativos à produção, emprego, produtividade, investimento, exportação, importação e saldo comercial da indústria de transformação, tanto em relação à comparação deste setor em face dos demais macrossetores da economia, quanto com base em uma avaliação intraindustrial segundo a classificação da OCDE por intensidade tecnológica. A conclusão a que se chega o autor é que alguns indicadores parecem sugerir a existência do processo de desindustrialização, enquanto outros parecem seguir o caminho oposto. O texto se destaca pela completude da análise sobre uma diversa gama de indicadores pouco usuais acerca do tema da desindustrialização. 
Já Martins e Lima (2015) defendem a hipótese de que o Brasil não estava preparado para o processo de desindustrialização iniciado na década de 1980, agregando mais uma análise de perfil predominantemente "novo-desenvolvimentista". Para isso, analisa, além dos indicadores usuais, como participação da produção industrial relativa ao PIB e a relação emprego industrial versus emprego total, índices não usuais, como o Produto Interno Bruto per capita e o Índice de Desenvolvimento Humano - IDH. Os autores concluem que o Brasil não possuía as características necessárias para a ocorrência da desindustrialização "natural", devido ao não atingimento de um estágio de desenvolvimento que lhe permitisse a ocorrência do processo na forma encontrada nos países desenvolvidos. ${ }^{4}$

Assim, com o objetivo de contribuir para o debate, a próxima seção abordará o padrão de evolução regional da indústria de transformação brasileira, com o intuito de esclarecer o comportamento interno da indústria nacional desde meados dos anos 1980, por meio dos indicadores usuais e do ponto de vista regional.

\section{Análise da situação brasileira sob a ótica das regiões}

Tendo o Brasil características regionais marcantes, a decomposição dos dados agregados num estudo sobre desindustrialização parece ser de grande valia para a comparação entre regiões distintas, na expectativa de encontrar padrão regional diferente do observado nos dados agregados. Ademais, a pesquisa bibliográfica realizada no decorrer deste trabalho não encontrou estudos similares, que fazem uso destes dados por região. Os indicadores aqui apresentados são os tradicionalmente aceitos, incluindo os conceitos propostos por Tregenna (2009): a participação do valor adicionado e a taxa de ocupação da indústria de transformação, frente ao PIB e à força de trabalho, respectivamente. Adicionalmente, faz-se uso da relação Valor da Transformação Industrial/Valor Bruto da Produção Industrial por região (VTI/VBPI regional), visando observar indicadores que melhor caracterizem as diferenças nos movimentos regionais, em seguida, discute-se sobre setores industriais ganhadores e perdedores numa perspectiva subsetorial

4 Os países desenvolvidos gozariam de um processo de desindustrialização "natural" ou positivo, sem impactos negativos para a economia. Países em desenvolvimento, como o Brasil, estariam passando por uma desindustrialização "prematura" ou "negativa". 
e regional e estima-se um modelo paramétrico, regredindo a participação das indústrias de transformação regionais nos respectivos PIBs com a renda per capita regional. Por fim, discutem-se os resultados estimados.

\subsection{0 valor adicionado}

A diminuição do VA da indústria de transformação como percentual do PIB, a preços básicos (Gráfico 1), é evidente a partir da segunda metade da década de 1980, com parcial reversão em períodos de câmbio desvalorizado, conforme observado em Marconi e Rocha (2012). A recente valorização cambial aparentemente tem contribuído no encolhimento da participação do subsetor indústria de transformação que, em 2012, atingiu o menor valor da série histórica apresentada, 13,25\%, desfazendo a "reversão parcial" de uma possível desindustrialização, observada por Oreiro e Feijó (2010, p. 225,) para dados até 2005.

\section{Gráfico 1 Brasil - participação da indústria de transformação no PIB - \%}

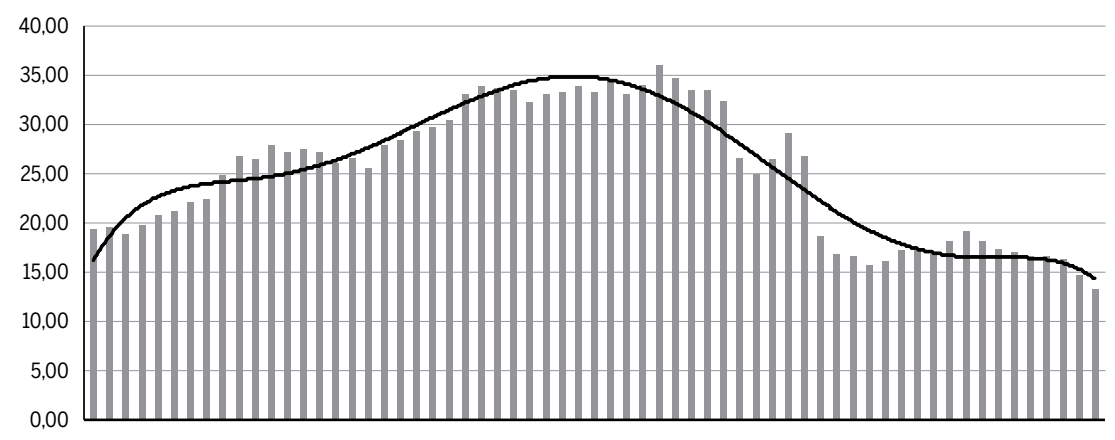

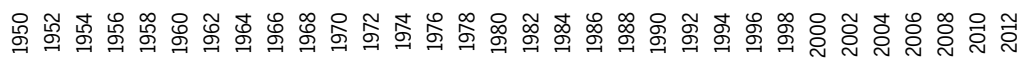

$\square$ PIB - indústria - transf. - VA - preços básicos - (\% PIB)

— Polinômio (PIB - indústria - transf. - VA - preços básicos - (\% PIB))

Fonte: Contas Nacionais, IBGE - Elaboração própria.

Antes de prosseguir, deve-se chamar atenção para a mudança metodológica promovida pelo Instituto Brasileiro de Geografia e Estatística - IBGE, no ano de 2007, com vistas à adaptação aos padrões internacionais de cálculo. O Instituto tomou o ano de 2000 como base, implantou mudanças 
metodológicas nas estimações, e recalculou a série histórica a partir de 1995, inviabilizando comparações entre a série anterior a 1995, que fora descontinuada em 2004, com a nova série (Oreiro; Feijó, 2010); (Torres; Silva, 2012).

Assim sendo, este artigo discorre sobre as duas séries históricas regionais para abrangência mais generalista. É atribuído cuidado especial para deixar claro sobre qual das séries se refere cada explanação. Neste caso, as análises serão divididas em dois períodos, o primeiro tem início em 1985 e fim no ano de 1994 e o segundo principia em 1995 e vai até 2010. ${ }^{5}$ Inicialmente, convém entender melhor sobre a participação de cada região do país no cálculo do valor adicionado nacional. Os gráficos 2 e 3 mostram a evolução da distribuição do VA nacional sob a ótica regional, tendo como base os anos de 1985 e 2000. A diminuição da participação das regiões Sudeste e Nordeste em relação ao total nacional, no período de 1985 a 1994, é de 2,7 e 0,99 pontos de participação, respectivamente. Todas as demais regiões tiveram sua participação levemente aumentada no período analisado. $\mathrm{Na}$ série histórica com as mudanças metodológicas, compreendendo o período de 1995 a 2010, o Sudeste é a única região que diminui a participação, com perda de 3,63 pontos. Apesar da clara tendência à desconcentração regional do produto, o Sudeste ainda responde por mais da metade do valor adicionado nacional, sendo, em 2010, responsável por 54,43\% do total.

Ao observar a distribuição dos dados nacionais setoriais por região, mais especificamente em relação à indústria de transformação, o padrão de evolução regional apresenta as seguintes tendências: ${ }^{6}$ na série histórica que se inicia em 1985 (gráfico 4) e vai até 1994, o Sudeste tem sua participação nacional reduzida em 6,72 pontos de participação, e o Nordeste reduz 1,04 pontos, enquanto todas as outras regiões elevam suas respectivas participações, com destaque para a região Sul, que aumentou em 5,56 pontos percentuais o valor adicionado de sua indústria de transformação em relação ao total do país. Na série mais recente (gráfico 5), que compreende os anos de 1995 até 2010, a diminuição da participação do Sudeste no VA da

5 Segundo o IBGE, a série com base em 1985 explica bem a economia brasileira até 1994, por esse motivo as análises com essa série se restringem ao período 1985-1994, apesar de haver dados disponíveis até o ano de 2004. Adicionalmente, analisou-se a série, com base no ano 2000 , entre 1995 e 2010 tendo em vista que os valores referentes a 2011 ainda estão sujeitos a modificações.

6 Chama-se atenção para o fato que os gráficos 4 e 5 se referem à evolução da distribuição do VA nacional oriundo do setor indústria de transformação, separados por região. 
indústria de transformação nacional continua, com perda de 4,3 pontos. As demais regiões são todas ganhadoras, contudo, os ganhos deste período são mais bem distribuídos, tendo as regiões Centro-Oeste, Nordeste, Norte e Sul, elevado suas respectivas participações em 1,96, 1,37, 0,59 e 0,38 . Assim, tem-se claramente uma tendência a uma reconfiguração do valor adicionado nacional da indústria de transformações entre regiões, com o Sudeste perdendo participação ao longo dos últimos 25 anos, o Sul se destacando nos ganhos e as demais regiões elevando levemente suas respectivas participações.

Para a análise específica por região, selecionou-se cada uma recalculando-se os pesos das indústrias de trasformação no VA regional para os anos compreendidos entre 1985 e 2011. Noutras palavras, as grandes regiões brasileiras foram tratadas como se fossem países com o intuito de analisar o padrão de evolução da indústria de transformação por região. Como era de se esperar, as regiões apresentaram padrões distintos entre si e entre o observado nos dados agregados do país. As três regiões com maior peso no PIB - Sudeste, Sul e Nordeste - mostraram comportamento análogo ao observado nos dados agregados para o Brasil a partir do ano de 1985 (gráfico 1). A tabela 1 apresenta as duas séries no tempo, referentes às duas metodologias de cálculo da participação da indústria de transformação regional no VA das regiões.

\section{Gráfico 2 e 3 Participação (\%) regional no valor adicionado bruto nacional a preço}

\section{básico - anos base 1985 e 2000}
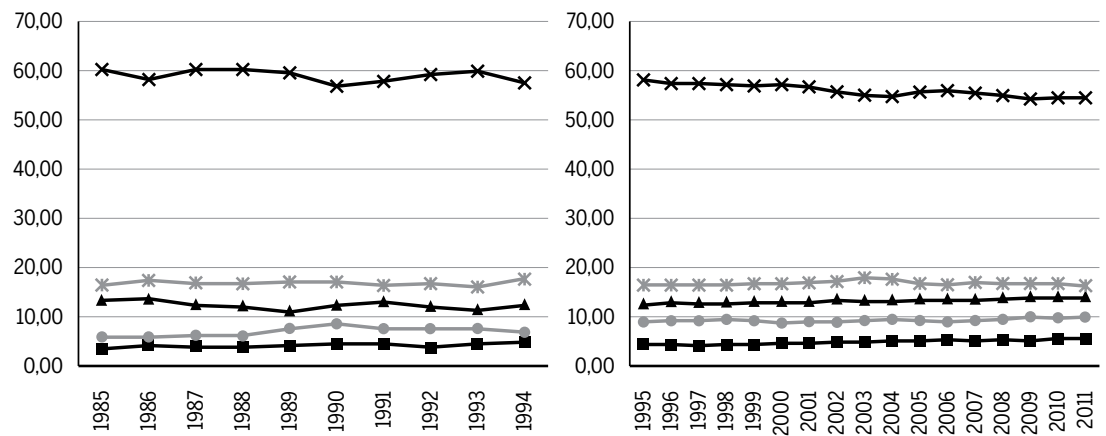

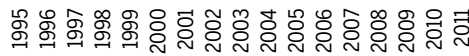
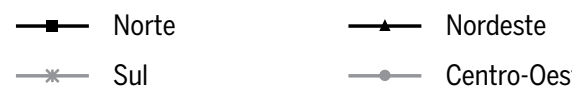

$\longrightarrow$ Sudeste

Fonte: Contas Regionais, IBGE - Elaboração própria. 
Gráfico 4 e 5 Participação (\%) das grandes regiões no valor adicionado bruto a preço básico da indústria de transformação nacional - anos base 1985 e 2000
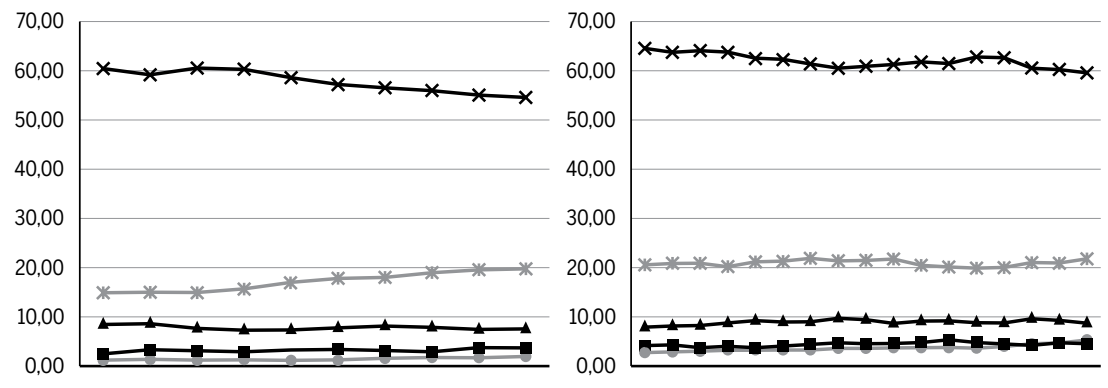

怘

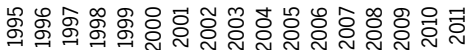

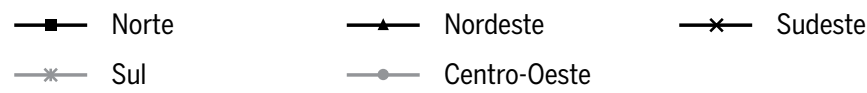

Fonte: Contas Regionais, IBGE - Elaboração própria.

O comportamento das séries de VA da indústria de transformação para a região Norte apresenta oscilações coerentes com os acontecimentos contemporâneos na economia brasileira, no entanto, a indústria de transformação da referida região apresenta melhor recuperação às crises internacionais do período em análise. Houve ganho de participação na primeira série temporal enquanto a segunda mostra relativa estabilidade.

Para a série que faz uso da antiga metodologia de cálculo do VA industrial, a região Norte inicia o período, em 1985, com a participação da indústria de transformação no VA da região em 35,01\%, e chega em 1994 com uma participação de $37,33 \%$, uma variação positiva de 2,32 pontos percentuais no VA regional. A análise da série com a nova metodologia de cálculo, que inicia em 1995, apresenta uma média de $25 \%$ do VA regional advindo da indústria de transformação, com períodos cíclicos negativos e positivos, inicia com $26,03 \%$ e termina o ano de 2010 com $25,18 \%$, diminuição de 0,85 pontos percentuais. No entanto, a indústria de transformação da região aparenta estar em recuperação dos efeitos da crise de 2008. Assim, de acordo com as séries de VA da indústria de transformação da região Norte, descarta-se a possibilidade de desindustrialização para a região, pois as duas séries temporais apresentam ganho na primeira parte do período e relativa estabilidade na segunda parte da série temporal da referida participação. 


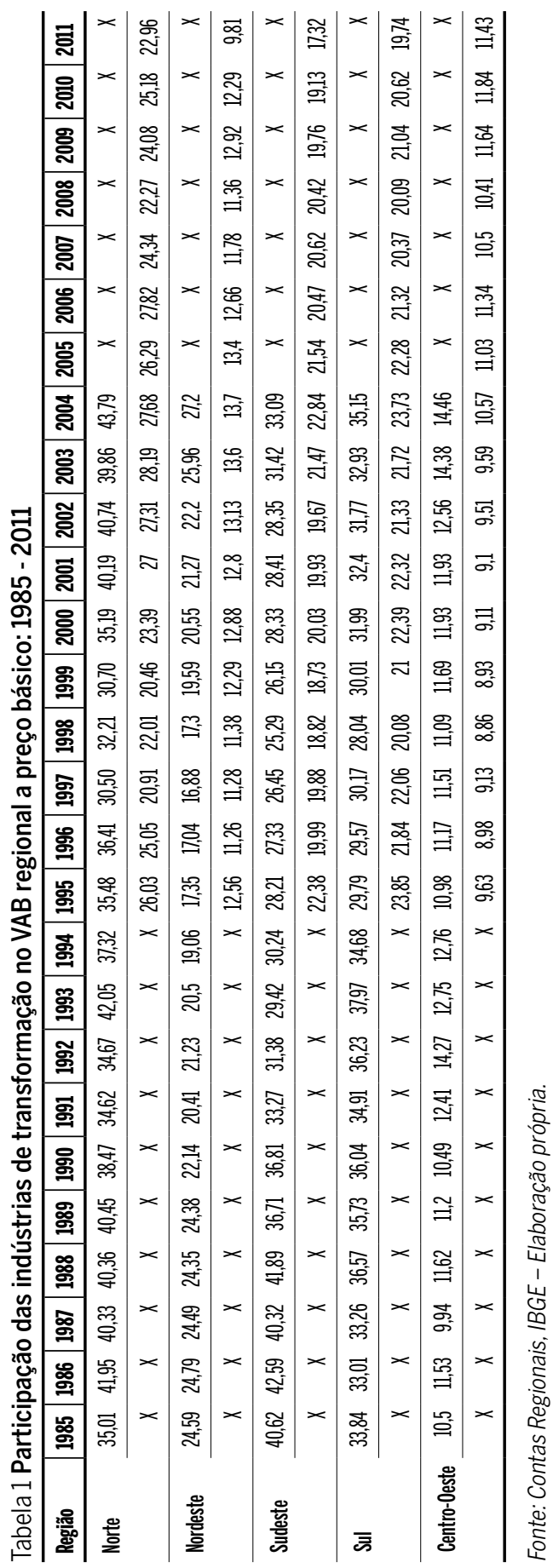


A região Nordeste apresenta comportamento diverso de acordo com o período em análise. A série de dados que vai de 1985 a 1994, com base em 1985, mostra a indústria de transformação do Nordeste perdendo fortemente participação no VA da região. Em 1985, a participação da indústria de transformação no VA regional era de 24,59\%, enquanto em 1994 a referida participação chegou a $19,06 \%$, ou seja, variou negativamente 5,53 pontos percentuais. A série temporal que inicia em 1995, com ano base 2000, mostra uma relativa estabilidade. A indústria de transformação regional foi responsável por 12,56\% e 12,29\% do VA regional nos anos de 1995 e 2010, respectivamente. Assim, de 1995 a 2010, a indústria de transformação nordestina reduziu levemente sua participação no VA regional em 0,27 pontos percentuais. Noutras palavras, com base neste indicador de desindustrialização, o Nordeste desindustrializou fortemente de 1985 a 1994 e apresentou relativa estabilidade no período de 1995 a 2010.

A região Sudeste é, aparentemente, a região que tem sofrido mais fortemente com o processo de desindustrialização. A série temporal de participação da indústria de transformação regional no VA da região com base em 1985, no período compreendido de 1985 a 1994, apresentou perdas de 10,38 pontos percentuais, com participação inicial de $40,62 \%$ e final, em 1994, de 30,24\%. Os anos seguintes, com base na série com nova metodologia de cálculo, apresentam continuidade do processo. Em 1995, a indústria de transformação regional sudestina era responsável por 22,38\% da geração do VA regional, já em 2010 a referida participação cai para $19,13 \%$, variação negativa de 3,25 pontos percentuais. Assim, a análise da participação do VA industrial na região Sudeste sugere fortes indícios de desindustrialização durante todo o período.

As séries temporais com a participação da indústria de transformação regional no VA da região Sul também apresentam indícios de desindustrialização, pelo menos para os anos pós-1995. A série que possui início e base no ano de 1985 apresenta uma participação de 33,84\% em 1985 e chega em 1994 com participação de 34,68\%, ganho de 0,84 pontos percentuais. No período seguinte, que vai de 1995 a 2010, o comportamento muda e inicia com participação de $23,85 \%$ e chega ao ano de $2010 \mathrm{com}$ participação de $20,62 \%$, queda de 3,23 pontos percentuais de participação industrial no VA regional. Neste caso, levando em conta o indicador de participação da indústria de transformação no VA regional, a região Sul apresenta também indicações de desindustrialização nos anos recentes. 
Por fim, a região Centro-Oeste apresenta variação positiva na participação da indústria de transformação no VA regional nas duas séries no tempo. A série que inicia em 1985 e termina em 1994, com a antiga metodologia de cálculo, em 1985 possuía 10,5\% de participação e termina em 1994 com $12,76 \%$, elevação de 2,26 pontos de participação. Na série seguinte a participação da indústria no VA regional em 1995 era de 9,63\% e chega em 2010 com 11,84\%, elevação de 2,21 pontos percentuais. Nesse caso, com base no indicador de participação da indústria de transformação no VA regional, descarta-se indícios de desindustrialização para a referida região.

Em suma, para o período compreendido entre 1985 a 2010 conclui-se que, em relação à participação da indústria de transformação regional no VA, Nordeste, Sudeste e Sul apresentam indícios de desindustrialização, enquanto as regiões Norte e Centro-Oeste seguem padrão contrário, com crescimento ou estabilidade na referida participação.

\subsection{Ocupação na indústria de transformação}

De acordo com Baer e Amann (2006), economias em desenvolvimento que desejem participar dos fluxos mundiais de comércio globalizado adotam, inevitavelmente, tecnologias modernas nos setores industriais, o que implica em diminuição da absorção de trabalhadores na indústria. Essa menor absorção dos empregos pela indústria liberaria a mão de obra para o setor de serviços, seguindo uma tendência natural à mudanças estruturais pelas quais essas economias passam com o crescimento da renda per capita. A referida tendência foi observada para a economia brasileira por meio do corte transversal de Kuznets por Baer et al. (2009). Contudo, será que a evolução decrescente em termos de participação relativa do emprego industrial frente ao emprego total observada para a economia nacional se sustenta para todas as regiões? Assim, seguindo a linha proposta por este artigo, de análise regional, deseja-se saber se há indícios de desindustrialização por região observando a evolução do emprego industrial das regiões frente ao emprego total regional.

Inicialmente, é importante salientar algumas peculiaridades nos dados sobre pessoal ocupado na indústria de transformação das regiões analisadas adiante. Primeiro, utilizou-se duas bases de dados, uma extraída da Pesquisa Mensal do Emprego (PME), para o período de 1991 à 2002, e outra para o período de 2002 em diante, oriunda da Pesquisa Nacional por Amostra de Do- 
micílios (PNAD). Utilizou-se duas bases por três motivos: os dados regionais da PNAD só estão disponíveis para anos a partir de 2002; os dados da PME são informações das pricipais regiões metrapolitanas, logo servirão de proxy para suas respectivas regiões e, por fim, a PME sofreu mudanças metodológicas na composição dos agrupamentos de atividade, tornando os dados pré-2002 (antiga-metodologia) não comparáveis com os pós-2002 (nova-metodologia). Em segundo lugar, cabe chamar atenção para o fato de que se fez uso de dados de pesquisas domiciliares (PME e PNAD). Note-se que este tipo de pesquisa adota o critério da autoclassificação dos entrevistados, podendo gerar distorções entre esses dados e as informações oriundas de pesquisas econômicas.

Conforme se observa no gráfico 6 , a tendência das séries em todas as RMs é cadente, entretanto, a série referente à RM de São Paulo é a que apresenta maior inclinação negativa, iniciando o período com aproximadamente $31 \%$ da ocupação e caindo para pouco mais de $20 \%$, uma diminuição de mais de 10 pontos percentuais. As demais regiões, Recife, Salvador, Belo Horizonte, Rio de Janeiro e Porto Alegre reduziram as proporções em, respectivamente, 3,$15 ; 4,42 ; 3,72 ; 6,37$ e 2,76 pontos percentuais. Todas as RMs, em conjunto, apresentaram variação média de $-7,32$ pontos percentuais. Aparentemente, durante toda a década de 90 houve perda de participação da população ocupada na indústria de transformação nas RMs. Para períodos selecionados de janeiro de 1991 à janeiro de 1995, e entre 1996 e 2000, não houve diferenças tendenciais, à exceção de Porto Alegre no período de 1991-1995, que se elevou levemente, mas que acompanhou as demais RMs a partir do ano seguinte com variações negativas da ocupação na indústria de transformação. Assim, em termos de participação da população ocupada na indústria de transformação, os dados da década de 90 parecem indicar na direção da existência de desindustrialização também em nível regional. Cabe lembrar que, para as regiões Centro-Oeste e Norte, não há regiões metropolitanas abrangidas pela PME para semelhante análise, concentrando-se as análises para as referidas regiões no período de 2002 à 2012.

Com relação ao período abrangido pela série de nova metodologia, o comportamento se mostra distinto ao da década anterior (gráfico 7). Nesse sentido, a série, para o Brasil, é relativamente estável, iniciando e concluindo a série com pouco mais de $13 \%$ de participação. Em termos regionais é que as diferenças aparecem. As regiões Norte e Sudeste apresentaram variações negativas de suas participações, nos montantes de $-2,9 \%$ e - $-1,1 \%$, enquanto as demais regiões tiveram elevação no percentual da participação do trabalho, tendo o 
Sul a maior elevação, de quase $2 \%$, e o Nordeste e o Centro-Oeste de apenas $0,3 \%$ e $0,5 \%$, respectivamente. Desse modo, nos anos que vão de 2002 a $2012^{7}$, há uma divergência de comportamentos regionais. Enquanto as regiões Norte e Sudeste somam indícios para ratificar um processo de desindustrialização, as regiões Nordeste, Centro-oeste e Sul caminharam na direção oposta.

Gáfico 6 Pessoas ocupadas (\%), segundo agrupamento de atividade indústria de transformação - regiões metropolitanas - antiga metodologia

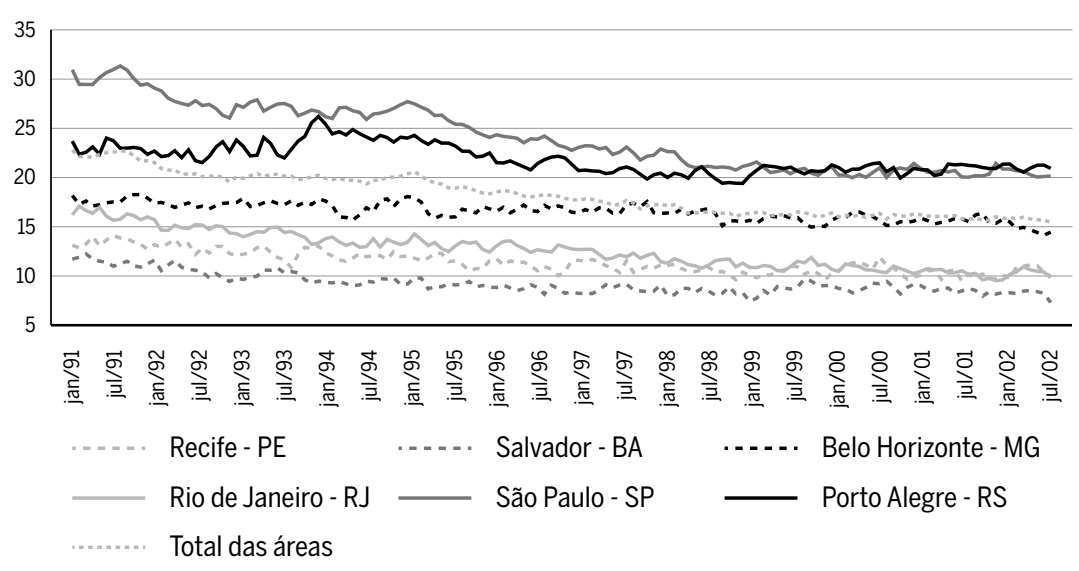

Fonte: Pesquisa Mensal do Emprego (PME), IBGE - Elaboração própria.

Gáfico 7 Pessoas ocupadas (\%), segundo agrupamento de atividade indústria de transformação - Brasil e regiões - nova metodologia

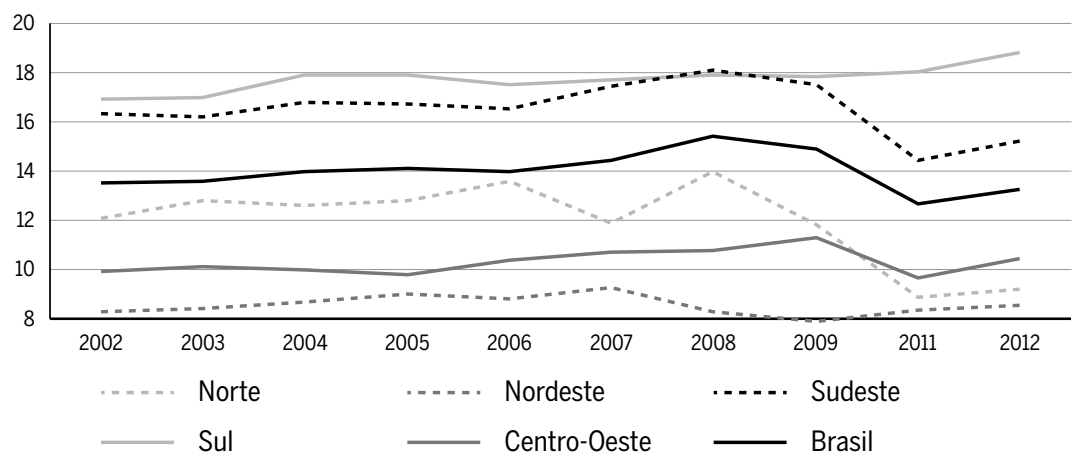

Fonte: Pesquisa Nacional por Amostra de Domicílios (PNAD), IBGE - Elaboração própria. 


\subsection{A relação $\mathrm{VTI} / \mathrm{VBPI}$ : diferenças regionais}

Tida como um indicador de desindustrialização, ${ }^{8}$ a relação Valor da Transformação Industrial/Valor Bruto da Produção Industrial (VTI/VBPI) afere o adensamento das cadeias produtivas (Carneiro, 2008, p.20): quanto menor a relação, menor a densidade da cadeia produtiva e, consequentemente, menor a agregação de valor do setor. Contudo, Torres e Silva (2012) apontam alguns problemas relativos a essa interpretação: em alguns setores os Custos com Operações Industriais (COIs ${ }^{9}$ ) possuem forte correlação com a taxa de câmbio real, ${ }^{10}$ além disso, a razão não leva em conta o encadeamento de um subsetor industrial com os demais subsetores da indústria local. Assim, pelas limitações da relação, o enfoque aqui adotado é de comparações intrarregionais das séries.

Conforme esperado, a evolução dos dados desagregados por região mostra maior correlação entre as séries do Sudeste/Sul com a do Brasil (valores em destaque na última coluna da tabela 2), levando a crer que a evolução da relação nacional é explicada pelas regiões de maior peso industrial. O mais provável é que as diferenças regionais na relação sejam advindas de características de seus mercados, como a distinta intensidade no uso de componentes importados na produção industrial, divergentes estruturas de mercados produtores e consumidores entre regiões, e incentivos diferenciados à produção, via tributos e crédito subsidiado direcionados à produção regional. ${ }^{11}$

8 A relação entre valor adicionado e valor da produção não é necessariamente um indicador do processo de desindustrialização. Pode ocorrer uma diminuição nessa relação e mesmo assim aumentar a participação do valor adicionado da manufatura no total. Basta que a produção industrial aumente proporcionalmente mais que nos demais setores e compense também a queda na relação entre VTI e VBPI.

9 Tendo em vista a limitação de espaço, para definições de VTI, VBPI e COIs, ver seção: "Conceitos das variáveis selecionadas da atividade industrial", disponível na PIA - IBGE, 2013.

10 Torres e Silva realizam a desagregação da indústria e encontram que existe correlação entre os COIs dos subsetores e a taxa de câmbio. Segundo os autores, "68\% dos COIs sofrem alguma interferência da taxa de câmbio, ampliando o escopo de setores industriais que podem apresentar erro de interpretação quando analisada a razão VTI/VBPI" (Torres; Silva, p. 11, 2012).

$11 \mathrm{Em}$ termos de incentivos tributários estaduais, podemos citar a disputa entre estados por empresas industriais de grande porte com isenções de impostos estaduais. Quanto a incentivo federal direto que favorece a descentralização, temos a zona franca de Manaus. Os incentivos via crédito subsidiado ficam por conta do BNDES, Banco do Nordeste, SUDENE e SUDAN. Para explanação sobre motivos que têm afetado a relação VTI/VBPI nacional ver Cano (p. 8, 2012) e Torres e Silva (p. 13, 2012). 
Tabela 2 Razão VTI/VBPI (\%) - indústria de transformação - por região e Brasil (1996-2011)

\begin{tabular}{|c|c|c|c|c|c|c|c|c|c|c|c|c|c|c|c|c|c|c|}
\hline Região & ஜ & চু & \& & ஓ् & 용 & 옹 & §్ర & ర్ర & ষ্ণ & 옹 & சீ & 용 & 号 & 용 & 응 & 곡 & $\begin{array}{l}\text { 咅 } \\
\text { 递 }\end{array}$ & $\rho$ \\
\hline Norte & 45 & 43 & 44 & 44 & 42 & 42 & 42 & 40 & 41 & 40 & 42 & 43 & 43 & 45 & 43 & 41 & 42 & 0,29 \\
\hline Nordeste & 46 & 43 & 44 & 45 & 45 & 45 & 43 & 41 & 40 & 41 & 44 & 43 & 45 & 44 & 45 & 45 & 44 & 0,39 \\
\hline Sudeste & 48 & 47 & 46 & 46 & 46 & 44 & 45 & 44 & 43 & 43 & 44 & 43 & 43 & 43 & 44 & 44 & 45 & 0,92 \\
\hline Sul & 44 & 44 & 43 & 44 & 42 & 41 & 41 & 40 & 38 & 38 & 39 & 38 & 38 & 41 & 42 & 42 & 41 & 0,79 \\
\hline Centro-0este & 37 & 37 & 36 & 35 & 32 & 35 & 35 & 36 & 34 & 36 & 35 & 32 & 33 & 35 & 37 & 37 & 35 & 0,29 \\
\hline Brasil & 47 & 46 & 46 & 46 & 46 & 45 & 45 & 44 & 43 & 43 & 44 & 43 & 42 & 42 & 43 & 43 & 44 & \\
\hline
\end{tabular}

Fonte: Pesquisa Industrial Anual (PIA), IBGE - Elaboração própria.

Cabe chamar atenção para a série da região Centro-Oeste, pois esta possui relação média inferior a todas as demais regiões e, consequentemente, abaixo da média brasileira (destaque na penúltima coluna da tabela 2) . Assim, a indústria de transformação ali localizada possui uma baixa capacidade de agregar valor, possivelmente em virtude de COIs mais elevados, dada a localização geográfica e o tipo de indústria da região. Por exemplo, segundo a Agência Nacional do Petróleo (ANP) (Brasil, 2013), o preço do óleo diesel comercializado na região Centro-Oeste foi, em média, 3,01\% mais caro do que o preço médio nacional para os anos de 2003 a 2012, enquanto os preços praticados na região Sudeste foram, em média, 0,41\% acima da média do Brasil para o mesmo período, com impactos diretos nos COIs regionais. Já em relação à geografia e ao tipo de indústria, a proximidade com o região Sudeste, onde estão localizadas a maior parte das atividades produtivas de bens de maior valor agregado e conteúdo tecnológico, gerando economias de aglomeração, cria dificuldades competitivas para a especialização da região Centro-Oeste na produção desses bens. Neste sentido, de acordo com Cruz e Santos (2011), em relação ao crecimento do emprego na indústria de transformação de 1990 a 2009, "a região Centro-Oeste está entre as maiores ganhadoras, com Goiânia e sudoeste de Goiás se destacando". Contudo, de acordo com a Confederação Nacional da Indústria (CNI, 2014), a indústria de alimentos do Centro-Oeste é responsável por mais da metade do Valor Adicionado Bruto industrial, participação bem superior a das demais regiões (Ver seção ganhadores e perdedores a seguir). 


\subsection{Ganhadores e perdedores: análise setorial e regional}

Ao discorrer sobre diferentes indicadores a respeito das regiões brasileiras, surge a questão: diante desse processo de desindustrialização regional, quais segmentos industriais ganharam e perderam? Bonelli et al. (2013) fazem uso de dados da PIA para calcular a evolução da participação dos subsetores da indústria de transformação no PIB, e mudanças estruturais no interior da indústria $^{12}$ no período que vai de 1995 a 2011. Os autores elencam como principais ganhadores as indústrias: i) de produtos fármaceuticos; ii) de máquinas e equipamentos; iii) de máquinas, aparelhos e materiais elétricos; iv) de outros equipamentos de transporte (inclui aeronaves); v) de automóveis. Perderam as indústrias: i) de vestuário e acessórios; ii) de couros e artefatos, inclusive calçados; iii) de produtos de madeira; iv) de produtos químicos; v) de borracha e material plástico; e vi) de produtos de metal exclusive máquinas e equipamentos. Contudo, quando a comparação é feita em relação ao PIB, apenas a indústria de outros equipamentos de transporte elevou sua participação, com destaque para a fabricação de aeronaves.

Cruz e Santos (2011) utilizam a variável pessoal ocupado como proxy para transformações no setor industria ${ }^{13}$ para o período de 1990 a 2009, seguindo a ótica regional. Assim, na tentativa de regionalizar os diversos segmentos da indústria de transformação que aparecem como ganhadores ou perdedores no trabalho de Bonelli, fez-se aqui uma agregação de resultados. Algumas características da dinâmica devem antes ser ressaltadas. Primeiro, as maiores perdas de empregos industriais se deram no Sudeste. Segundo, a perda de empregos na referida região se concentrou em indústrias trandicionais,${ }^{14}$ havendo, assim, uma especialização em empregos de indústrias com maior conteúdo tecnológico. ${ }^{15}$ Para Cruz e Santos (2011, p. 40):

12 Cabe lembrar que são ganhos e perdas relativas à participação na indústria de transformação nacional.

13 Para Lautert e Araújo (2007), "a concentração geográfica da indústria pode ser analisada a partir de indicadores como o VBPI, VTI ou a partir de informações referentes ao pessoal ocupado nas atividades industriais. Nos dois primeiros casos, os dados nem sempre estão disponíveis com o grau de desagregação desejado em que são necessários dados em nível de estabelecimento". Para uma breve discussão das limitações do uso de dados de pessoal ocupado como Proxy, ver Lautert e Araújo (p. 354, 2007).

14 Indústria tradicional aqui definida como o agregado das indústrias de madeira e mobiliário, borracha, fumo e couro, calçados, têxtil, alimentos e bebidas.

15 Para indústrias mais avançadas tecnologicamente, incluíram-se química, metalurgia, minerais não metálicos, eletrônicos e comunicações, material de transporte e mecânica. 
Regiões periféricas, como as localizadas no Nordeste, tendem a atrair indústrias de menor conteúdo tecnológico, enquanto as microrregiões que já contavam com uma estrutura industrial diversificada tendem a criar mais empregos em setores mais avançados tecnologicamente. Isto é, as microrregiōes ganhadoras em indústrias mais avançadas foram aquelas que já possuíam uma base industrial diversificada, ou seja, os fatores locacionais (como mercado de trabalho com mão de obra qualificada, acesso a fornecedores e ao mercado consumidor e externalidades de aglomeração) ou economia de aglomeração seriam mais importantes para indústrias mais avançadas tecnologicamente que incentivos fiscais ou custo de mão de obra.

Nesse contexto, os setores indústriais ganhadores no Nordeste foram as indústrias, predominantemente tradicionais, de calçados, têxteis, de alimentos e de bebidas,. Todas essas indústrias perderam participação nos dados relativos ao Brasil, conforme Bonelli et al. (2013). Nas regiões do polígono industrial do Centro-Sul, com parque industrial mais diversificado e próximas da microregião mais dinâmica, houve ganho significativo de empregos em indústrias tecnologicamente mais avançadas, indústrias estas que, em geral, estão entre as ganhadoras no estudo de Bonelli et al. (2013). Salienta-se que a única indústria que teve ganho de participação frente ao $\mathrm{PIB}$, a de outros equipamentos de transporte, inclusive fabricação de aeronaves, é fortemente concentrada na região Sudeste. Por fim, a indústria automotiva, que obteve expressivo ganho relativo ${ }^{16}$ no interior da indústria, possui elevada concentração nos estados do Sudeste e Sul do país.

A região Norte, ganhadora ou mantedora de participação industrial no PIB, mostrou reconfiguração da indústria de transformação, tendo o estado do Pará apresentado perdas relativas durante todo o período analisado, ratificando o estudo de Cruz e Santos (2011). A análise cruzada do referido artigo com os achados deste trabalho confirmam que na região Centro-Oeste, região que se industrializou, o estado de Goiás elevou a participação de sua indústria no VA e cresceu sua participação relativa na região.

Para melhor perceber as mudanças no interior da indústria de transformação das regiões e estados, selecionamos o VTI setorial de 1990, 1995, 2000, 2005, 2010 e 2012, (ano mais recente disponível) obtidos na PIA IBGE, para análise dos segmentos regionais. Análise semelhante é realizada por Guimarães Neto e Santos (2014), apenas para a região Nordeste para os anos 2000 e 2010. Como há problemas de compatibilidade entre períodos distintos ao longo da série no tempo, realizamos agregações de atividades

16 Ganhos relativos em grande parte motivados pelo aumento da renda da população, pela expansão e barateamento do crédito e pela existência de políticas industriais efetivas para o setor, como a redução da alíquota do IPI, Inovar Auto, etc. 
para tornar os anos das séries minimamente comparáveis, principalmente no que se refere à categoria dos bens (ver quadro $1 \mathrm{em}$ anexo). As análises são relativas no interior da indústria de transformação e seguem a diferença do ano de 2012 em relação ao ano de 1990. Adicionalmente, restringem-se às regiões que apresentaram desindustrialização, ou seja, diminuição da participação da indústria de transformação no valor adicionado.

O Nordeste (tabela 3) apresentou crescimento da participação de bens não-duráveis de consumo (+3,1 p.p.), uma elevada perda na participação dos bens intermediários (-5,64 p.p.), pequeno crescimento dos bens duráveis de consumo e de capital (+0,65 p.p.) e leve crescimento de outros (+1,9 p.p.). Nos não-duráveis, os segmentos que "capitanearam" o crescimento foram alimentos e bebidas (+5,98 p.p.) e preparação de couros e fabricação de artefatos de couro, artigos de viagem e calçados (+6,61 p.p.), apesar da grande perda de participação dos têxteis (-7,82 p.p.). Nos bens intermediários, a diminuição foi advinda dos segmentos de fabricação de produtos químicos ${ }^{17}$ (-8,37 p.p.) e metalurgia básica (-7,7 p.p.). Por fim, a pequena elevação na produção de bens duráveis de consumo e de capital foi devido ao crescimento dos segmentos fabricação e montagem de veículos automotores, reboques e carrocerias e fabricação de outros equipamentos de transporte (em conjunto $+4,41$ p.p.), que teve como contrapeso a redução da participação de máquinas e equipamentos ${ }^{18}$ (conjuntamente $-3,76$ p.p.).

As mudanças de participação no Sudeste (tabela 4) foram: leve aumento na categoria de Bens não-duráveis de consumo (+1,09 p.p), relativa estabilidade em bens intermediários (+0,78 p.p.), diminuição na participação relativa da categoria de bens duráveis de consumo e de capital (-2,71 p.p.) e estabilidade na categoria outros (+0,84 p.p.). $\bigcirc$ crescimento dos bens não-duráveis de consumo foi influenciado pelo crescimento em fabricação de produtos alimentícios e bebidas (+7,59 p.p.) e contrabalanceados por diminuições nos segmentos de fabricação de produtos têxteis e confecção de artigos do vestuário e acessórios (-3,37 p.p. e -2,58 p.p. respectivamente). O pequeno aumento na participação de bens intermediários deveu-se ao crescimento de fabricação de coque, refino de petróleo, elaboração de combustíveis nucleares e produção de

17 Somatório de: fabricação de produtos químicos, produtos farmacêuticos e medicinais; fabricação de produtos farmoquímicos e farmacêuticos e produtos de perfumaria, sabões e velas. A mesma agregação será feita na análise dos dados das demais regiões.

18 Somatório de: fabricação de máquinas e equipamentos; fabricação de máquinas para escritório e equipamentos de informática, fabricação de máquinas, aparelhos e materiais elétricos; fabricação de material eletrônico e de aparelhos e equipamentos de comunicações. $\bigcirc$ mesmo será adotado para análise dos números do Sudeste e do Sul. 


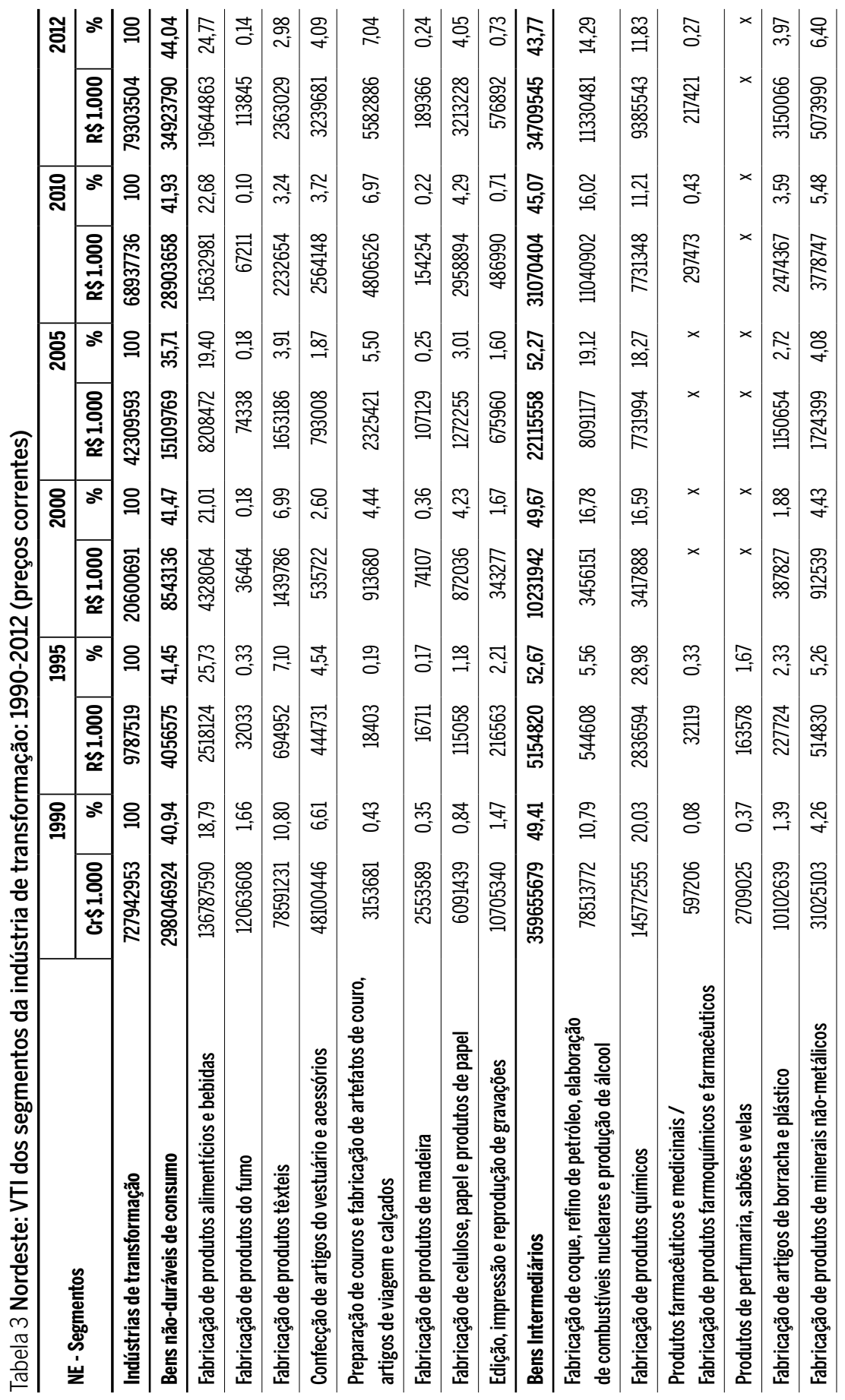




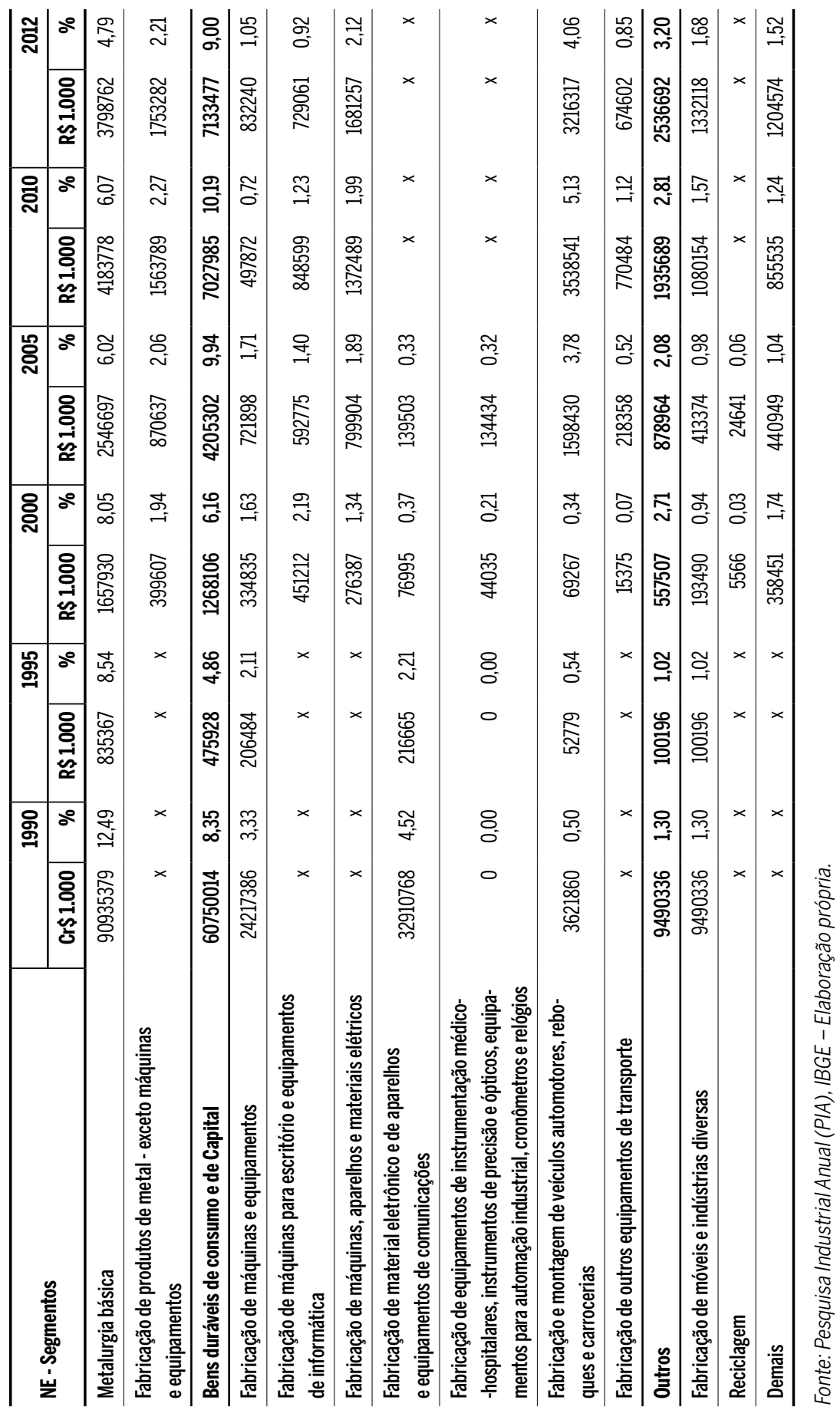




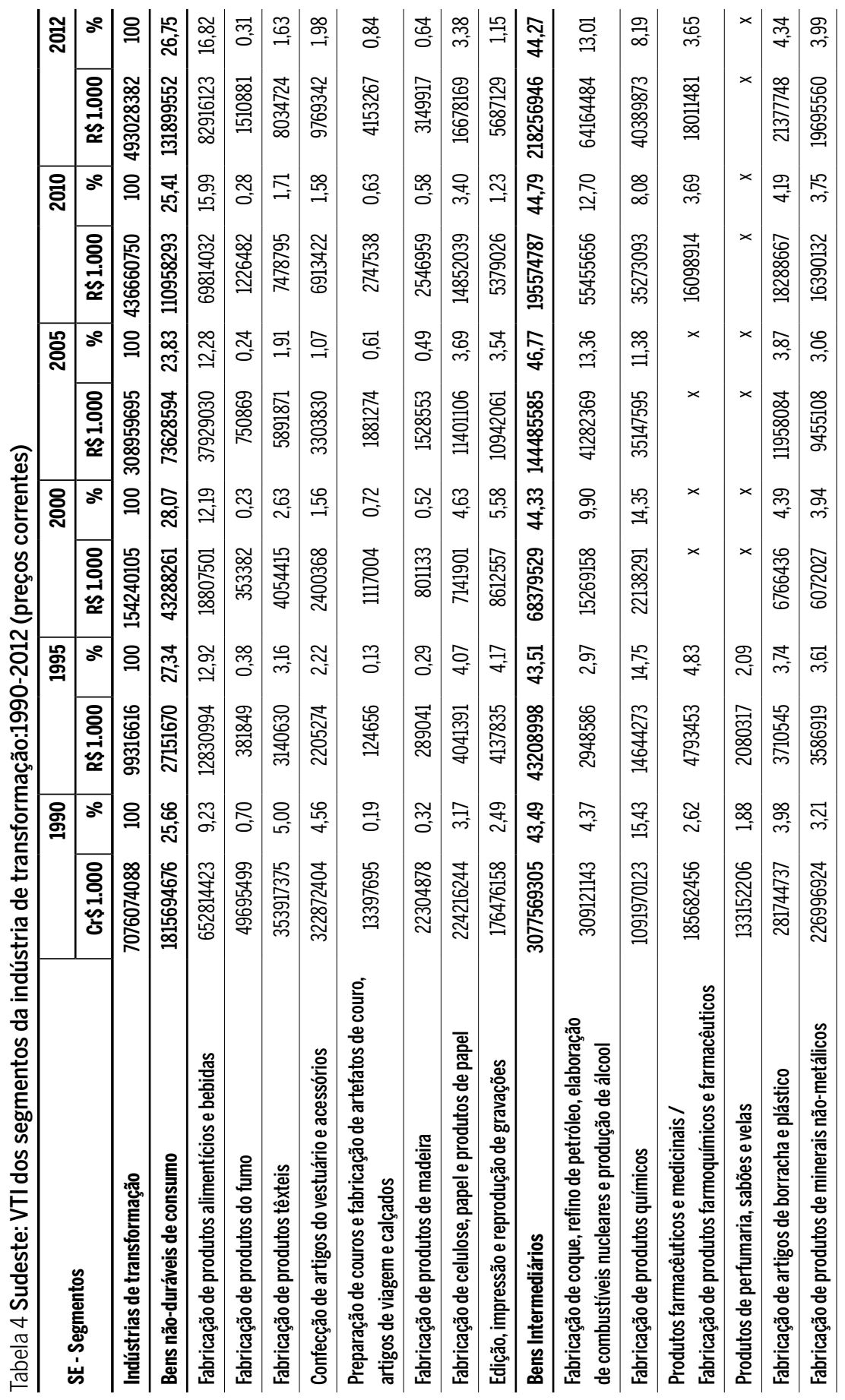




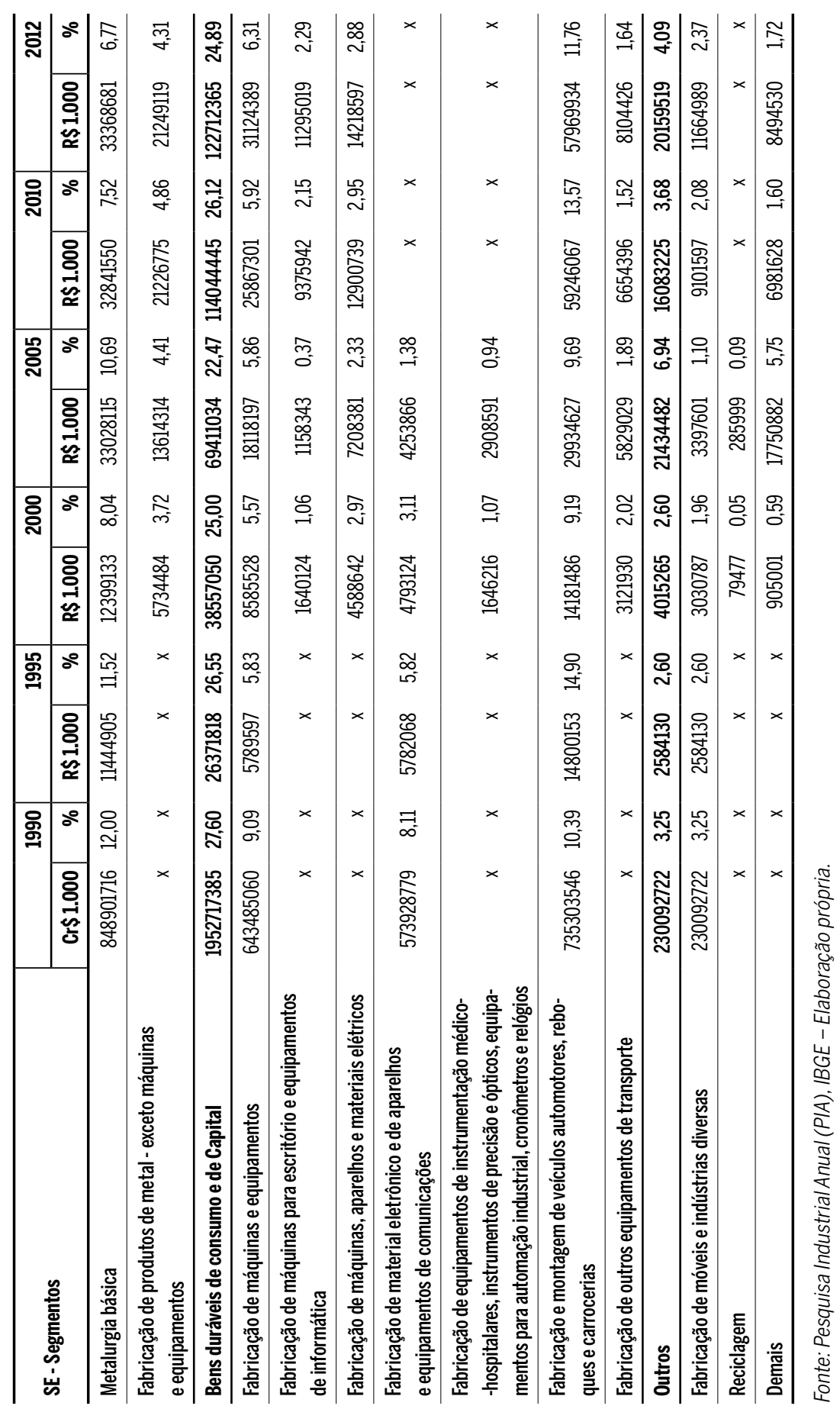




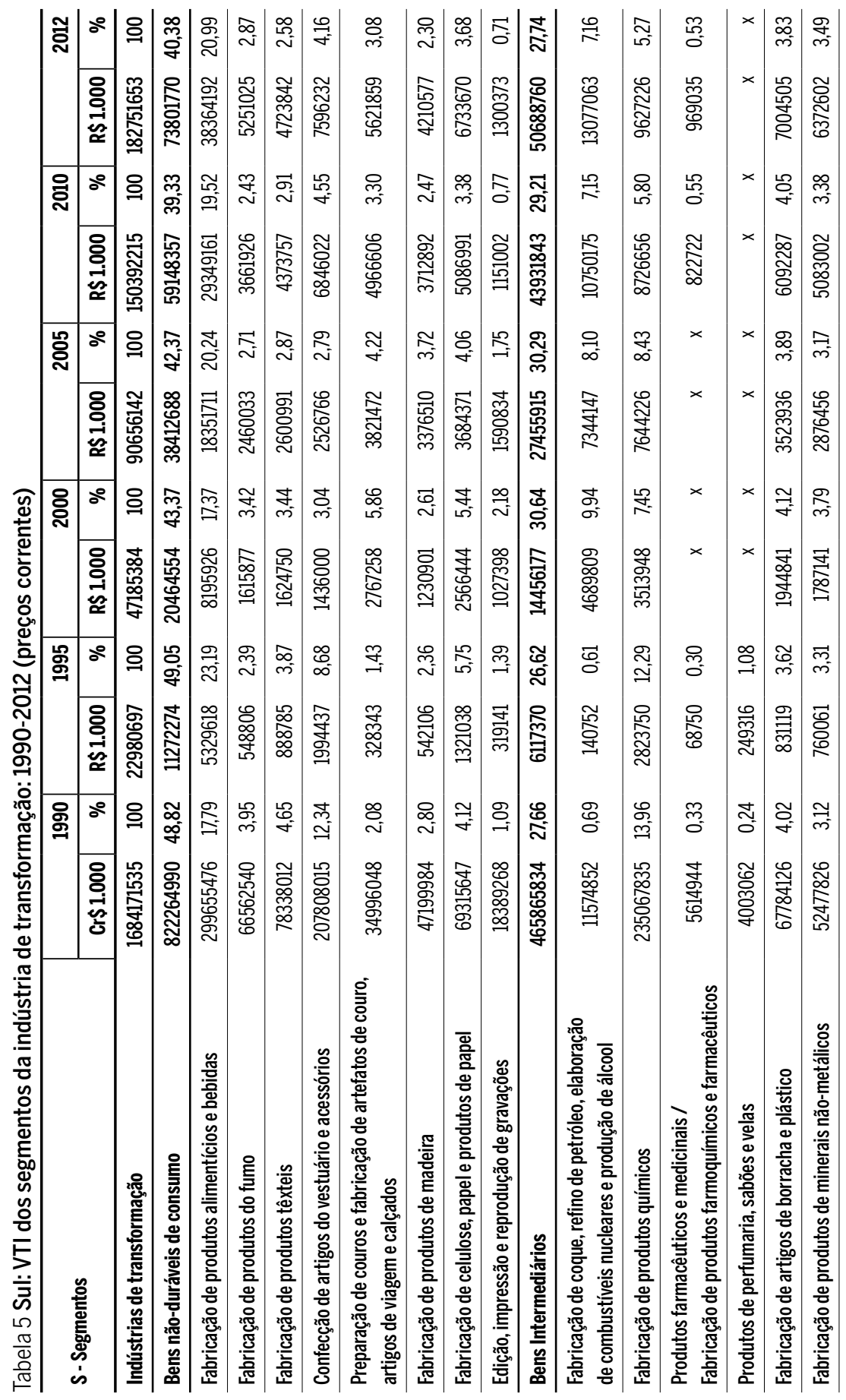




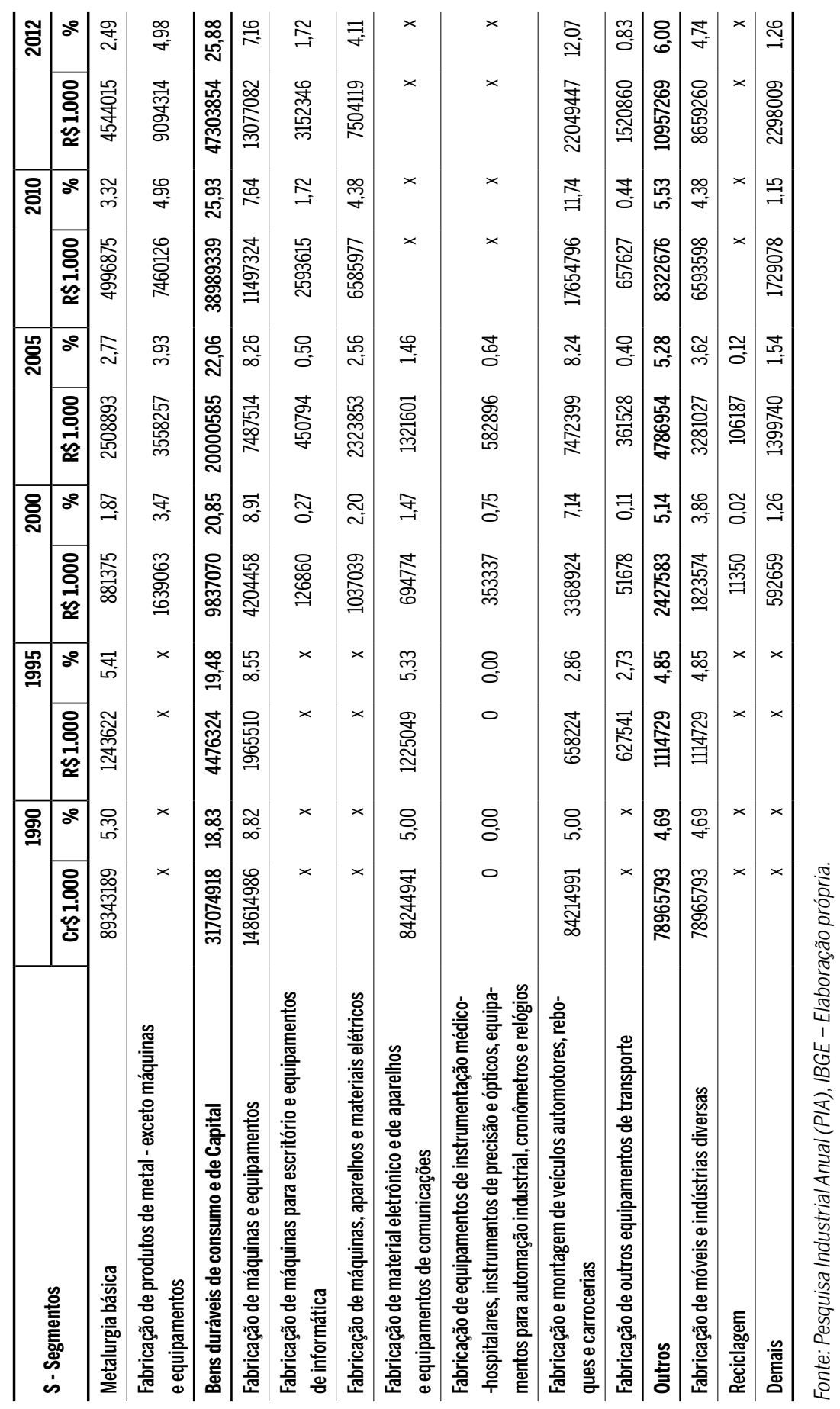


álcool (+8,64 p.p.), compensado pela diminuição no segmento de produtos quimicos (-8,09 p.p.). Finalmente, os bens duráveis de consumo e de capital, de maior valor adicionado, tiveram crescimento na fabricação e montagem de veículos automotores, reboques e carrocerias e fabricação de outros equipamentos de transporte (em conjunto $+3,01$ p.p.), mas elevada perda de participação no conjunto de segmentos de máquinas e equipamentos (-5,72 p.p.).

O Sul (tabela 5) apresenta o seguinte panorama: grande diminuição na categoria de Bens não-duráveis de consumo (-8,44 p.p), estabilidade na participação da categoria de bens intermediários ( $+0,07$ p.p.), grande crescimento relativo nos bens duráveis de consumo e de capital $(+7,06$ p.p.) e leve aumento em outros (+1,31 p.p.). A diminuição nos não-duráveis de consumo foi fortemente influenciada pela queda na participação de confecções de artigos do vestuário e acessórios (-8,18 p.p.). O equilíbrio na participação dos bens intermediários foi fortemente influenciado pela diminuição da participação do segmento fabricação de produtos químicos (-8,73 p.p.), contrabalançado pelo crescimento na fabricação de coque, refino de petróleo, elaboração de combustíveis nucleares e produção de álcool (+6,47 p.p.). Por fim, o crescimento dos duráveis de consumo e capital foi motivado quase que inteiramente pelo crescimento na fabricação e montagem de veículos automotores, reboques e carrocerias e fabricação de outros equipamentos de transporte (em conjunto $+7,9$ p.p.).

Num balanço mais geral percebe-se que no Nordeste os bens duráveis de consumo e capital, apesar do leve crescimento relativo recente, representam menos de $10 \%$ da indústria de transformação regional, enquanto no Sudeste e Sul a referida participação é de aproximadamente $25 \%$, tendo o Sul apresentado crescimento relativo no mesmo período. Em outras palavras, existe uma tendência à especialização regional das indústrias possuidoras de maior conteúdo tecnológico no Sul e Sudeste, provavelmente motivada pelos efeitos discutidos por Cruz e Santos (2011), conforme explicitado anteriormente. Assim, pode-se concluir que, no balanço líquido de ganhos e perdas dos segmentos industriais por regiões do Brasil, a tendência à descentralização das indústrias tradicionais, apresentada em Cruz e Santos (2011) não parece clara, pois duas das três regiões que apresentam desindustrialização elevaram participação dos segmentos tradicionais (ver quadro 2 em anexo). Adicionalmente, a participação relativa do valor da produção de bens duráveis e de capital se elevou no Nordeste e Sul, ainda que em velocidades diferentes. Nos grupos de bens interme- 
diários, apenas o Nordeste registrou diminuição de participação, contudo, todas as regiões apresentam grandes variações de participação no valor relativo da produção dos segmentos deste grupo.

\section{Possíveis causas do processo}

Entender possíveis razões do comportamento diverso entre regiões é desafiador. Principalmente se essas diferenças tiverem origem no processo histórico de formação econômica das regiões, como é o caso do Brasil. Sendo assim, adotaremos a linha de análise sobre causas discutidas na literatura sobre desindustrialização e detalhadas em Oreiro e Feijó $(2010)^{19}$, mas não nos restringiremos a elas, tendo em vista que elementos adicionais são necessários para a discussão das diferenças regionais de desindustrialização.

Segundo Palma (2005), os fatores externos foram preponderantes no processo de desindustrialização brasileira (Palma, 2005, p. 37-38):

Monetarismo radical dos anos 80 (...), [o] aumento repentino nas exportações de produtos primários (...) [e a] drástica virada da política econômica (...) resultado de um programa radical de liberalização financeira e comercial dentro do contexto de um processo global de reforma econômica e mudança institucional que levou a uma brusca reversão da estratégia de industrialização ISI (guiados pelo Estado) dos países.

Para as regiões, a inserção comercial externa parece reforçar o peso da abertura comercial e financeira da liberalização econômica. Regiões mais protegidas e, em maior grau, dependentes de intervenção estatal direta como o Nordeste, sentiram mais fortemente a diminuição do ativismo estatal da década de 90. Já no caso da região Sudeste, a desindustrialização ocorrida no primeiro momento, com a abertura comercial e financeira, parece ter contribuído para a industrialização observada na região Sul, assim como para a mudança na estrutura produtiva em favor da produção de bens de maior valor agregado como bens duráveis e de capital.

Ainda no que tange a fatores externos, para a década de 2000, não podemos desconsiderar o efeito do comércio bilateral com a China sobre as

19 Segundo Oreiro e Feijó, fatores internos e externos influenciam o processo de desindustrialização. Fatores internos são: "uma mudança na relação entre a elasticidade renda da demanda por produtos manufaturados e serviços" e "crescimento mais rápido da produtividade na indústria do que no setor de serviços". Fatores externos são "relacionados ao grau de integração comercial e produtiva das economias, ou seja, com o estágio alcançado pelo assim chamado processo de 'globalização'” (Oreiro; Feijó, p. 222, 2010). 
commodities e bens industrializados, efeito direto, e entre os países que comercializam com Brasil e China e que têm aumentado o comércio com este em detrimento daquele, efeitos indiretos. Segundo Jenkins (2015, p.19,):

There is clear evidence that China has contributed to deindustrialization in Brazil since the middle of the past decade. However, the relationship is more complex than it is often portrayed as one of "unfair competition" from subsidized Chinese manufactures.

$\mathrm{Na}$ tentativa de observar esse efeito sobre as distintas regiões do Brasil, é necessário chamar atenção para questões como o grau de abertura comercial e financeira e impactos da globalização do ponto de vista regional, principalmente em regiões onde a indústria de transformação expandiu as trocas com a China. Ferreira e Arruda (2011), fazendo uso de dados do Ministério do Desenvolvimento, Indústria e Comércio Exterior (MDIC), chamam atenção para a evolução do comércio das grandes regiões do Brasil com a China que em 2001 era de 3,6; 7 e 8,1 pontos de participação (p.p) para as regiões Nordeste, Sudeste e Sul, respectivamente, e em 2010 evoluíra para 33,8, 28,2 e 16,9 p.p..

No intuito de qualificar esse avanço no comércio bilateral por região, segundo Melo (2013), considerando os anos de 2000 a 2010, a região Nordeste tem elevado o peso dos insumos industriais oriundos da China. A expansão e consolidação das cadeias globais de comércio estariam conduzindo o Brasil, e em particular o Nordeste, a se comportar como mero montador de bens duráveis, particularmente dos setores eletroeletrônico e, com menor intensidade, automobilístico. No que se refere à região Sul, para o mesmo período:

A estrutura produtiva do setor na região permaneceu praticamente inalterada, os termos de competição no mundo se alteraram, principalmente com a entrada, em larga escala, dos produtos chineses a preços relativos muito baixos. Não conseguindo enfrentar concorrentes, empresas antes produtoras tornaram-se entreposto comercial, perdendo, a região toda, um capital - financeiro e de conhecimentos - antes em operação. (Montibeller Filho; Gargioni 2014, p. 318).

Já o Sudeste, por contar com um parque industrial relativamente maduro com a estrutura produtiva industrial mais diversificada, possui um comércio externo mais concentrado em bens manufaturados e de maior nível tecnológico, em consequência disso, menos vulnerável à competição externa. De acordo com Ferreira e Arruda (2011), "a contribuição do setor externo para a atividade industrial regional depende fundamentalmente da natureza do setor exportador de cada região...". Os autores analisaram a dinâ- 
mica da atividade industrial e seus transbordamentos regionais e externos. A conclusão é que, "apenas o Sudeste reagiu positivamente, enquanto que Nordeste e Sul apresentaram uma queda na dinâmica industrial em resposta a choques no setor externo. Portanto, verifica-se a presença de spillovers positivos do setor externo apenas sobre a região Sudeste do Brasil".

Já no que ser refere a aspectos internos, fugiremos às análises tradicionais e elencaremos alguns motivos pelo qual o processo de desindustrialização acomete as regiões brasileiras em diferentes momentos no tempo e no espaço. Um desses fatores internos é o perfil das cadeias produtivas das indústrias regionais. É sabido que na década de 1980 a região Sudeste possuía uma indústria relativamente madura e com os setores industriais diversificados (ver tabela 4), com a produção industrial melhor distribuída. Nesse caso, é de se esperar que o perfil da desindustrialização que acometeu a referida região possua um caráter mais próximo da desindustrialização em países desenvolvidos, com a saída de subsegmentos não competitivos e/ou de perfil tecnológico mais tradicional, os quais são mais suscetíveis à incentivos fiscais e à mão de obra abundante e barata. Já a região Sul parece ter passado por uma fase de amadurecimento e finalização do desenvolvimento de cadeias produtivas entre os anos de 1980 e 1990 (ver tabela 5), período de abertura comercial brasileira, a partir de quando tem recebido efeitos negativos similares aos enfrentados na região vizinha, o Sudeste.

No Nordeste os acontecimentos foram, aparentemente, processados de forma diferente. A abertura comercial e financeira sobre a indústria de transformação teve seus efeitos negativos mais sentidos em regiões mais dependentes do estado e com cadeias produtivas industriais ainda incipientes, dependentes de proteção estatal. Não por acaso, a desindustrialização nessa região foi mais forte entre os anos finais de 1980 e início dos anos 1990. Na década seguinte, a região Nordeste teve o fenômeno minimizado pelo crescimento da renda regional, motivada em grande parte pelas transferências de renda, aumento do salário mínimo real e elevação do investimento, sendo esses condicionados pela retomada das políticas de intervenção governamental nas decisões econômicas da região.

Outro fenômeno não desprezível que diverge entre as três regiões acometidas em algum grau pela desindustrialização é o perfil societário das empresas locais. A justificativa teórica é que empresas de capital estrangeiro são mais afeitas a investimentos em segmentos industriais de perfil 
tecnológico mais elevado, em consequência disso, produtores de maior valor adicionado. Por exemplo, Rossi e Santos (2014, p. 443), fazendo uso de dados da PIA e PINTEC, encontraram que "empresas de capital estrangeiro apresentam produtividade média superior à produtividade média das empresas de capital nacional e misto em todo o período" que vai de 2000 a 2009.

Nesse sentido, a distribuição geográfica dessas empresas estrangeiras industriais, segundo a origem do capital controlador, quantifica essas diferenças. Na tabela 6, percebe-se que a participação de empresas multinacionais no Sudeste em relação ao Brasil é de aproximadamente 75 p.p., enquanto o Nordeste possui apenas 4 p.p.. As participações em termos de multinacionais inovadoras regionais em relação ao total delas no Brasil possuem as mesmas participações de 75 e 4 p.p para Sudeste e Nordeste, respectivamente. Adicionalmente, no que se refere a multinacionais brasileiras com sedes nas regiões, de acordo com Ranking FDC das multinacionais brasileiras (2015), cerca de $65 \%$ dessas empresas possuem sede no Sudeste, $29 \%$ no Sul e apenas 4\% no Nordeste. Assim, de maneira geral, percebe-se que a região Nordeste conta com menor presença de multinacionais e empresas industriais inovadoras do que o Sudeste e Sul.

Tabela 6 Empresas estrangeiras industriais, total e inovadoras, segundo a origem do capital controlador - Brasil, sudeste e nordeste: 2006-2008

\begin{tabular}{l|r|r|r|r|r}
\hline \multirow{2}{*}{ Empresas } & \multicolumn{4}{r}{} & \multicolumn{2}{|r}{ 2006-2008 } \\
\cline { 2 - 7 } & Brasil & SE & NE & SE/BR (\%) & NE/BR (\%) \\
\hline Total & 2371 & 1773 & 102 & 75 & 4 \\
\hline Inovadoras & 1325 & 996 & 56 & 75 & 4 \\
\hline Inovadoras (\%) & 56 & 56 & 55 & - & - \\
\hline
\end{tabular}

Fonte: Adaptado de Paixão (2014, p. 97).

Por fim, mas não menos importante na busca por razões para o comportamento dos dados de desenvolvimento industrial regional, a infraestrutura. Segundo Frischtak (2013), nas décadas de 1980 e 1990, o Brasil passou por contrações de investimentos em infraestrutura, como percentual do PIB, nos montantes de $33 \%$ e $36 \%$ respectivamente, quando comparados aos da década de 1970. Na década de 2000, ainda de acordo com Frischtak, os níveis de investimentos em infraestrutura foram similares aos da década anterior, entre 2 e 2,5\% do PIB. Esse panorama é 
ainda mais adverso em regiões onde a infraestrutura é deficiente, como é particularmente a do Nordeste.

O que dizer então sobre como a indústria reage frente ao cenário de carência em infraestrutura? Fleury (2009) fez uso de dados em painel para verificar o impacto dos investimentos em infraestrutura com os objetivos da política industrial e conclui que investimentos em infraestrutura geram menor aceleração no setor industrial do que no setor de serviços, mas em ambos os casos o impacto é positivo e significante estatisticamente. Adicionalmente, no que se refere a aspectos das intensidades tecnológicas, ainda segundo Fleury (2009, p. 153), "investimentos em infraestrutura alteraram de forma relevante a produtividade da mão de obra", levando a crer que regiões (ou países) com maior nível de renda per capita e maior participação dos setores industriais e de serviços no PIB tenderiam a responder positivamente, ou seja, a taxas decrescentes, às inversões em infraestrutura.

Como observado por Frischtak (2013), a participação dos investimentos em infraestrutura no PIB tem diminuído no Brasil nas últimas três décadas. Não por acaso, o período coincide com o horizonte temporal em que o país registra desindustrialização, tanto em escala global quanto regional (em três regiões). Fazendo uso dos argumentos expostos acima por Fleury (2009), talvez as regiões Sudeste e Sul, possuidoras de um nível de infraestrutura maior do que as demais regiões do Brasil, venham enfrentando dificuldades para tirar vantagem desse quesito na questão industrial. Primeiro pelo baixo nível de investimentos, segundo pelo retorno decrescente que esses investimentos possuem sobre a indústria de transformação. Neste sentido, supondo que as regiões receberam investimentos em infraestrutura proporcional às suas respectivas participações no produto interno bruto, as regiões Centro-Oeste, Norte e Nordeste contariam, em algum grau, com efeitos positivos de uma infraestrutura menor, mas em crescimento, sobre o crescimento industrial regional. Contudo, como observado ao logo deste trabalho, a região Nordeste não parece ter se beneficiado fortemente desse apoio, dado que apresentou desindustrialização na década de 1990 e estagnação no crescimento industrial da década seguinte. Não se deseja aqui explorar em profundidade o quesito da infraestrutura, tendo em vista a ausência de dados regionais sobre o tema, mas apenas chamar atenção para esse aspecto de grande relevância para o desenvolvimento industrial e do país. 


\subsection{A relação de $\mathrm{U}$ invertido por região}

Um argumento comumente observado em trabalhos sobre desindustrialização é que as economias industriais, em determinado estágio de desenvolvimento, passam a perder participação relativa da indústria no PIB. Rowthorn e Ramaswamy (1999) observaram que existe uma relação não linear (relação de U invertido) entre a participação do emprego industrial no emprego total e o nível de renda per capita dos países, para isso os autores utilizaram dados de 70 países. Palma (2005) aprofunda essa análise mostrando que esse processo não acontece igualmente em países com diferentes estágios de desenvolvimento. Nesse sentido, ele elaborou um modelo de regressão similar ao proposto por Rowthorn e Ramaswamy (1999) e trabalhou dados de 81 países, concluindo que existem quatro fontes diferentes de desindustrialização entre os diversos países. ${ }^{20}$ Cruz e Santos (2011) repetiram o exercício para o Brasil e regrediram a participação relativa da indústria de transformação no PIB e na renda per capita. Todos os autores chamam a atenção para o fato de que apenas o nível de renda per capita não é suficiente para explicar a evolução da participação da indústria no PIB.

Para analisar as diferenças regionais da desindustrialização brasileira, estimou-se um modelo paramétrico semelhante ao utilizado por Palma (2005), Rowthorn e Ramaswamy (1999) e Cruz e Santos (2011), para cada região do Brasil. $O$ modelo possui a seguinte forma:

$$
\text { Partind }=\beta_{0}+\beta_{1}^{*} \ln \left(P I B_{p c}\right)+\beta_{2}^{*}\left(\ln \left(P I B_{p c}\right)\right)^{2}+\varepsilon
$$

em que, Partind é a participação da indústria de transformação regional no PIB, em porcentagem; PIBpc é o PIB per capita em dólares constantes de 2005 e o $\varepsilon$ é o termo de erro da regressão. Analisaram-se os dados regionais disponíveis de 1966 a $2010^{21}$. Para as regiões que apresentaram

20 As quatro fontes são: a) uma relação de "U invertido" entre o emprego industrial e a renda per capita; b) uma relação em declínio entre renda per capita e emprego industrial; c) um declínio na renda per capita correspondendo ao ponto de virada da regressão; d) a doença holandesa. Para detalhamento das fontes, ver Palma (2005).

21 Salienta-se que há uma grande dificuldade na obtenção de dados regionais para anos anteriores a 1985, fato que tornou impossível uma série de dados completa ano a ano e, em consequência, um melhor ajuste do modelo. Adicionalmente, para as regiões Norte e Centro-Oeste não havia dados para o ano de 1975, havendo informações para as demais regiões. Procedemos com a imputação dos dados faltantes com a interpolação das informações existentes para 1970 e 1980 [(dado de 1970 + dado de 1980)/2]. 
indícios de desindustrialização, todos os coeficientes mostraram-se significantes conjuntamente, aferidos a partir do teste $\mathrm{F}$ e considerando um nível de significância de 1\% (ver tabela 7). Adicionalmente, os coeficientes individuais são todos significantes ao nível de 1\% para o Brasil e para as regiões Sudeste, Sul e Nordeste. As rendas (PIBpc) associadas ao início na diminuição da participação das indústrias de transformação regionais nos respectivos PIBs são diferentes, sendo de 2.100, 5.763 e 4.646 (US\$ de 2005) para as regiões Nordeste, Sudeste e Sul, respectivamente. Já para o Brasil, a renda associada foi de 3.977. Os valores das rendas das regiões selecionadas são relativamente próximos ao nível de renda per capita dos países considerados por Palma (2005) como de desindustrialização precoce (Ver tabela 8 em anexo). Os gráficos de 18 a 23 mostram os ajustes das regressões lineares.

Para garantir que a escolha do modelo não direcionou o resultado, aplicou-se um Smoother Lowess ${ }^{22}$ aos dados e se estimou um modelo polinomial local. Nas três situações, os gráficos mostraram comportamento semelhante. ${ }^{23}$ Dado que este exercício trata regiões brasileiras como países, destaca-se que o fato de a perda de participação da indústria do Nordeste no PIB é prematura em relação às regiões Sudeste e Sul, tendo em vista o baixo nível de renda per capita associada ao início do processo e o perfil subsetorial da indústria do Nordeste que era, de modo geral, composto de indústrias tradicionais, diferentemente das existentes no Centro-Sul do país. Adicionalmente, conforme discutido na seção de perdedores e ganhadores, a região Sudeste perdeu em indústrias tradicionais, tendo as indústrias de maior intensidade tecnológica um padrão de evolução inverso.

Por fim, deve-se chamar atenção para o fato de que o $\mathrm{R}^{2}$ dos modelos paramétricos variou de 0,25 a 0,61, ou seja, outras variáveis são necessárias para explicar a evolução da participação da indústria de transformação por região. A relação não linear entre a participação da indústria e a renda per capita, assim como a velocidade em que se apresentou a redução de peso, carecem de melhor argumentação teórica, com a observação do impacto de políticas públicas na dinâmica do crescimento de longo prazo das regiões. Contudo, não é a proposta deste trabalho a construção ou discussão dessa argumentação.

22 Regressão linear localmente ponderada com o intuito de suavizar o comportamento dos dados.

23 Gráficos disponíveis em: http://www.coreconpe.org.br/iiienpecon/artigos/73enpecon 2014.pdf. 
Gráficos 8 a 13 Regressões paramétricas com termo quadrático para Brasil e regiões
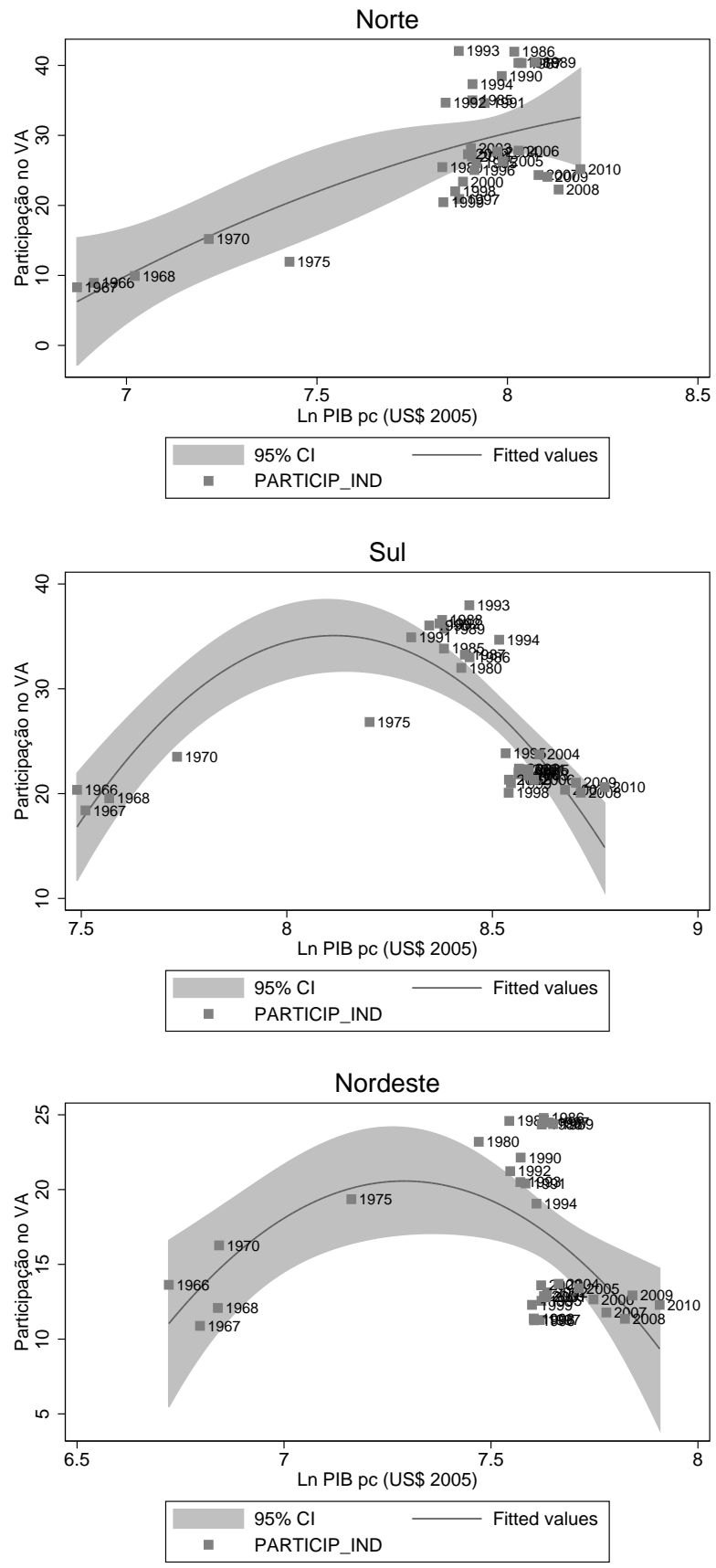

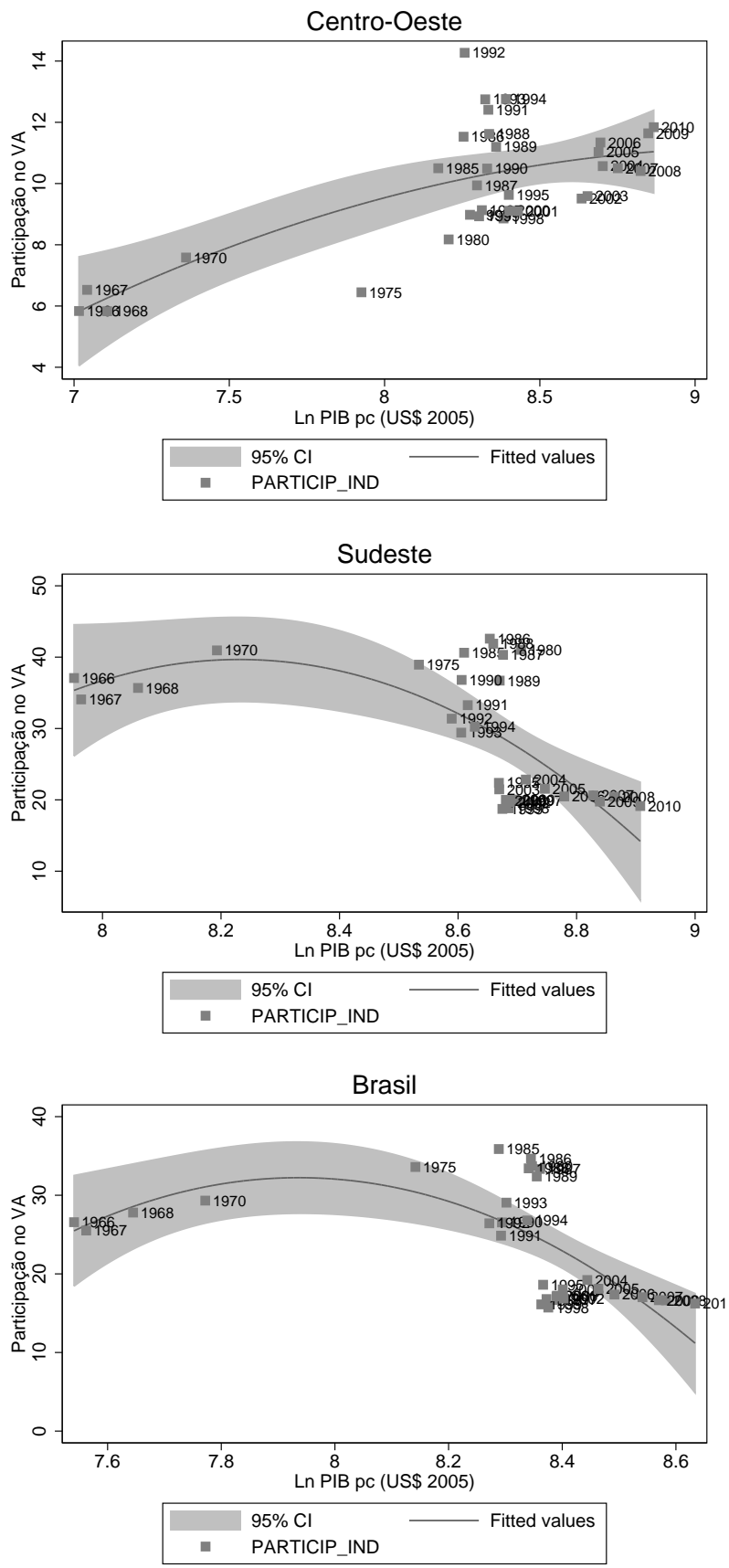

Fonte: dados das Contas Nacionais e Regionais do IBGE. 
Tabela 7 Estatísticas do modelo paramétrico

\begin{tabular}{lrrrr|r|r|r}
\hline Parâmetro & Norte & Nordeste & Sudeste & Sul & Centro-0este & Brasil \\
\hline$\beta_{0}$ & $-537,3135$ & $* * *-1545,739$ & $* * *-3729,664$ & $* * *-3037,942$ & $-82,15081$ & $* * *-2692,497$ \\
\hline$\beta_{1}$ & $(667,8002)$ & $(334,2488)$ & $(935,9847)$ & $(461,5908)$ & $(53,56158)$ & $(600,4879)$ \\
\hline & 128,7582 & $* * * 429,6881$ & $* * * 915,9052$ & $* * * 757,3611$ & 20,23404 & $* * * 686,6596$ \\
\hline$\beta_{2}$ & $(179,9235)$ & $(91,68481)$ & $(223,1017)$ & $(114,8164)$ & $(13,73776)$ & $(149,6626)$ \\
\hline & $-7,225338$ & $* * *-29,46922$ & $* * *-55,6386$ & $* * *-46,66385$ & $-1,096651$ & $* * *-43,26122$ \\
\hline R-squared & $(12,0668)$ & $(6,266065)$ & $(13,26855)$ & $(7,114364)$ & $(0,872156)$ & $(9,298865)$ \\
\hline $\mathrm{F}(2,29)$ & 0,5152 & 0,2556 & 0,3847 & 0,6155 & 0,4928 & 0,3976 \\
\hline
\end{tabular}

Fonte: dados das Contas Nacionais e Regionais do IBGE.

Nota: 32 observações por região. ${ }^{*} p<0,1 ;{ }^{* *} p<0,05$; ${ }^{* *} p<0,01$.

\section{Considerações finais}

O presente trabalho discutiu a hipótese de desindustrialização da economia brasileira a partir de uma perspectiva regional, à luz da teoria econômica usualmente aceita sobre o tema.

Os dados de valor adicionado pela indústria de transformação como proporção do PIB nacional mostram que a participação do VA industrial no PIB segue diminuindo, possivelmente motivada pela contínua apreciação cambial iniciada em 2004 e sustentada até meados de 2013. Já a análise dos dados de VA desagregados por região sugere uma tendência à desconcentração regional do VA industrial, tendo em vista a diminuição da participação da região Sudeste e a elevação, ainda que suave, das demais regiões. A análise dos dados da participação da indústria de transformação regional no VA da região indica que Nordeste, Sudeste e Sul têm diminuído suas participações, tendo as demais regiões apresentado comportamento contrário, seja quando o horizonte temporal vai de 1985 a 1994 (antiga metodologia) seja quando analisamos o período de 1995 a 2011 (nova metodologia). Assim, em termos de VA na indústria de transformação, Nordeste, Sudeste e Sul apresentam indícios de desindustrialização, as outras duas regiões elevaram ou mantiveram suas respectivas participações de VA industrial (transformação) no VA regional, sendo os dados nacionais fortemente influenciados pelas indústrias de transformação das três regiões "perdedoras". 
A análise de dados regionais de pessoal ocupado na indústria de transformação fez uso de duas bases de dados: PME, para Regiões Metropolitanas (como Proxy das regiões), e PNAD, para regiões do país. Os períodos selecionados foram de 1991 a 2002, antiga metodologia de cálculo, e de 2002 a 2012, nova metodologia. Para a década de 1990, os dados sugerem haver redução da participação da população ocupada na indústria de transformação, indicando a existência de desindustrialização também em nível regional para as três regiões analisadas (Nordeste, Sudeste e Sul). Já para o período de 2002 a 2012, as regiões Norte e Sudeste parecem estar em processo de desindustrialização, enquanto as regiões Nordeste, Centro-oeste e Sul caminharam na direção oposta.

As diferenças regionais em termos da relação VTI/VBPI reforçam a hipótese de que os dados nacionais são fortemente influenciados pelos números do Sudeste e Sul, possuindo as séries elevada correlação com a nacional. $\bigcirc$ balanço de ganhadores e perdedores, do ponto de vista das indústrias regionais e setores que a compõem, mostrou que a tendência à descentralização da indústria de transformação, exposta por Cruz e Santos (2011), não é clara. Todavia, existe uma tendência à especialização regional das indústrias com maior conteúdo tecnológico no Sudeste e Sul. Nas indústrias consideradas tradicionais, apenas a região Sul apresentou diminuição de participação deste grupo de segmentos.

A breve discussão sobre as razões desse processo numa escala regional fez uso de elementos explicativos consagrados na literatura de desindustrialização, fatores externos e internos, que em maior ou menor grau influenciaram a dinâmica das indústrias de transformação regionais. Sobre componentes externos, a abertura comercial e financeira e a mudança na atuação do estado na economia na década de 1990 atingiu mais fortemente Sudeste e Nordeste, por razões distintas, em função do grau de desenvolvimento das cadeias produtivas dessas regiões. Por fim, com repercussões reestruturadoras das cadeias produtivas industriais na década de 2000, o "efeito China", tanto sobre o câmbio quanto sobre trocas diretas e indiretas, tem impactado mais fortemente regiões menos competitivas internacionalmente no ambiete industrial, sejam elas Nordeste e Sul.

Já no que se refere a motivos de ordem interna, o diferente nível de especialização das indústrias regionais justifica porque, na região Sudeste, o processo se assemelha à desindustrialização que acomete os países desenvolvidos, enquanto a ocorrência no Nordeste, em particular, trata-se 
de elemento mais desestruturador em função da incompletude das cadeias de produção industrial na região. Outro fator de ordem interna é o perfil societário das empresas nas regiões. Esse aspecto influencia fortemente o grau de abertura comercial, a política de investimentos na indústria e o nível de agregação de valor da produção industrial regional. Nesse sentido, o Sudeste possui larga vantagem frente às demais regiões, em números absolutos e relativos de multinacionais na região, assim como em número de multinacionais brasileiras com sede nas regiões. Finalmentea última razão de ordem interna abordada neste trabalho, a infraestrutura, tem afetado todas as regiões do Brasil, contudo, os resultados paracem ser diferenciados em virtude do espaço geográfico e do tempo em termos de desenvolvimento industrial e econômico.

Por fim, nos resultados da estimação do modelo paramétrico, chama-se a atenção para o baixo nível de renda per capita do Nordeste, relativamente a Sudeste e Sul, no momento em que a indústria de transformação começou a perder participação, não chegando à metade do nível destas rendas. Apesar das disparidades, as três regiões possuíam nível de renda per capita similar às rendas dos países considerados de desindustrialização precoce nos termos de Palma (2005). Cabe, então, aprimorar a discussão teórica sobre as causas e consequências das diferenças regionais desse processo, o que será objeto de próximos trabalhos sobre o tema.

\section{Referências}

BAER, W.; AMANN, E. Neoliberalismo e concentração de mercado no Brasil: A emergência de uma contradição?.In: BAER, W. A economia brasileira. Editora Nobel: São Paulo, p. 494$507,2009$.

BAER, W.; FONSECA, M. A. R.; GUILHOTO, J. J. M. Mudanças estruturais na economia industrial do Brasil, 1960-95. In: BAER, W. A economia brasileira. Editora Nobel: São Paulo, p. 473-493, 2009.

BONELLI, R.; PESSOA, S.; MATOS, S. Desindustrialização no Brasil: fatos e interpretação. In: BACHA, E.; BOLLE, M. B. O Futuro da Indústria no Brasil: desindustrialização em debate. Civilização Brasileira: Rio de Janeiro, 2013. p. 45-80.

CANO, W. A desindustrialização no Brasil. Economia e Sociedade, Campinas, v. 21, Número Especial, p. 831-851, dez. 2012.

CARNEIRO, R. Impasses do desenvolvimento brasileiro: a questão produtiva. Textos para Discussão, Campinas: IE/UNICAMP, n. 153, nov. 2008.

CRUZ, B. O.; Santos, I. R. S. Dinâmica do emprego industrial no Brasil entre 1990 e 2009: 
uma visão regional da desindustrialização. Ipea - Texto para discussão 1673. Rio de Janeiro, nov. 2011.

CURADO, M. Industrialização e desenvolvimento: uma análise do pensamento econômico brasileiro. Economia e Sociedade, Campinas, v. 22, n. 3 (49), p. 609-640, dez. 2013.

FEIJÓ, C. A; CARVALHO, P. G; ALMEIDA, J. S. G. Ocorreu uma desindustrialização no Brasil?. São Paulo: IEDI, Novembro, mimeo, 2005.

FERREIRA, R. T.; ARRUDA, E. F. Dinâmica da atividade industrial brasileira e seus spillovers regionais e externos. In: XXXIX Encontro Nacional de Economia - Anpec 2011. Disponível em: < http://anpec.org.br/encontro/2011/inscricao/arquivos/289-087e5b97a675c32055de1ff0d9caf45a.pdf >. Acesso em 01/11/2015.

FLEURY, F. L. Investimentos em infraestrutura como instrumento de política industrial. Tese (Doutorado em Administração) - Faculdade de Economia, Administração e Contabilidade, Universidade de São Paulo, São Paulo, 2009. Disponível em: <http://www.teses.usp.br/teses/ disponiveis/12/12139/tde-27032009-113110/>. Acesso em: 2015-11-18.

FRISCHTAK, C. Infraestrutura e desenvolvimento no Brasil. In: VELOSO, F.; FERREIRA, P. C.; GIAMBIAGI, F.; PESSÔA, S. Desenvolvimento econômico - uma perspectiva brasileira. Rio de Janeiro, Elsevier, 2013, p. 322-346.

GUIMARÃES NETO, L.; SANTOS, V. M. Economia do Nordeste: perfil atual e tendências relevantes. In: NASCIMENTO, A.; LIMA, M. C. Nordeste brasileiro em questão: uma agenda para reflexão. Editora UFPE, Recife, p. 119-166, 2014.

INSTITUTO BRASILEIRO de Geografia e Estatística - IBGE. Contas Nacionais e Regionais (SCN e SCR). Disponível em: <http://www.ibge.gov.br>. Acesso em fevereiro de 2014.

INSTITUTO BRASILEIRO de Geografia e Estatística - IBGE. Pesquisa Industrial Anual (PIA). Disponível em: <http://www.ibge.gov.br>.

INSTITUTO BRASILEIRO de Geografia e Estatística - IBGE. Conceitos das variáveis Selecionadas da Atividade Industrial. Disponível em: <http://www.ibge.gov.br/home/estatistica/ economia/industria/pia/atividades/conceitos.shtm> Acesso em maio e outubro de 2014.

INSTITUTO BRASILEIRO de Geografia e Estatística - IBGE. Pesquisa Industrial Mensal Produção Física (PIM-PF). Disponível em: <http://www.ibge.gov.br>. Acesso em fevereiro de 2014.

INSTITUTO BRASILEIRO de Geografia e Estatística - IBGE. Pesquisa Mensal de Emprego (PME). Disponível em: <http://www.ibge.gov.br>. Acesso em fevereiro de 2014.

INSTITUTO BRASILEIRO de Geografia e Estatística - IBGE. Pesquisa Nacional por Amostra de Domicílios (PNAD). Disponível em: <http://www.ibge.gov.br>. Acesso em fevereiro de 2014.

JENKINS, R. Is chinese competition causing deindustrialization in Brazil?. Latin American Perspectives. Jul. 2015.

LAUTERT, V.; ARAÚJO, N. C. M. de. Concentração industrial no Brasil no período 19962001: uma análise por meio do índice de ellison e Glaeser. Economia Aplicada, São Paulo, v. 11, n. 3, p. 347-368, Jul.-Set. 2007.

MARCONI, N.; ROCHA, M. Taxa de câmbio, comércio exterior e desindustrialização precoce - o caso brasileiro. Economia e Sociedade, Campinas, v. 21, Número Especial, p. 853-888, dez. 2012. 
MARTINS, G. N.; LIMA, J. P. R. Evidências da precoce desindustrialização no Brasil. Nexos Econômicos, v. 9, n. 1, Jan-Jun. 2015.

MELO, M. C. P. Comércio exterior da região Nordeste na esteira do "efeito china". Revista Econômica do Nordeste, Fortaleza, v. 44, n. 2, p. 453-474, abr-jun. 2013.

MONTIBELLER FILHO, G.; GARGIONI, S. L. Desenvolvimento da região Sul do Brasil. In: MONTORO, G. C. F. et al. Um olhar territorial para o desenvolvimento: Sul. Rio de Janeiro, BNDES, 214, $512 \mathrm{p}$.

NASSIF, A. Há evidências de desindustrialização no Brasil?. Revista de Economia Política, v. 28, n.1, 2008.

OREIRO, J. L.; FEIJÓ, C. A. Desindustrialização: conceituação, causas, efeitos e o caso brasileiro. Revista de Economia Política, São Paulo, v. 30, n. 2, 2010.

PAIXÃO, M. C. S. Investimento estrangeiro direto industrial no cenário ambiental e socioeconômico do Nordeste brasileiro. Brasília, Tese de doutorado, Universidade de Brasília - UNB. 2014. Disponível em: < http://repositorio.unb.br/handle/10482/16301 >. Acesso em 01/11/2015.

PALMA, J. G. Four sources of "de-industrialization" and a new concept of the "dutch disease". In: Beyond Reforms - Structural dynamics and macroeconomic vulnerability. Stanford University Press and The World Bank. Washington, 2005.

RANKING FDC das multinacionais brasileiras 2015 - A capacidade de adaptação cultural das empresas brasileiras no mundo. 2015. Disponível em: < https://www.fdc.org.br/blogespacodialogo/Documents/2015/ranking_fdc_multinacionais_brasileiras2015.pdf >. Acesso em 01/11/2015.

ROSSI, M. C. T.; SANTOS, G. F. Impacto do investimento direto externo sobre os ganhos de produtividade na indústria brasileira. In: X Encontro de Economia Baiana, 2014. Disponível em: < http://www.eeb.sei.ba.gov.br/pdf/2014/er/impacto_do_investimento.pdf >. Acesso em $01 / 11 / 2015$.

ROWTHORN, R.; RAMASWANY, R. Growth, Trade and Deindustrialization. IMF Staff Papers, v. 46, n.1, 1999.

SONAGLIO, C. M.; ZAMBERLAN, C. O.; LIMA, J. E.; CAMPOS, A. C. Evidências de desindustrialização no Brasil: Uma análise com dados em painel. Economia Aplicada, v. 14, n. 4, p. 347-372, 2010.

SQUEFF, G. C. Desindustrialização: luzes e sombras no debate brasileiro. Ipea - Texto para discussão 1747. Brasília, jun. 2012.

TREGENNA, F. Characterizing deindustrialization: an analysis of changes in manufacturing employment and output internationally. Cambridge Journal of Economics, vol. 33, n. 3, mai. 2009

TORRES, R. L.; Silva, H. C. Uma crítica aos indicadores usuais de desindustrialização no Brasil. In: XL Encontro Nacional de Economia - Anpec 2012. Disponível em <http://www. anpec.org.br/encontro_2012.html>. Acesso em janeiro de 2014.

WASQUES, R. N. O fenômeno da desindustrialização: uma análise do caso paranaense no período 1990-2010. Revista Economia e Tecnologia. v. 8, n. 1, p. 67-76, jan./mar. 2012.

WASQUES, R. N.; TRINTIM, J. G.. Uma análise do desempenho da indústria de transformação brasileira na década de 1990: ocorreu um processo de desindustrialização?. In: XL 
Encontro Nacional de Economia - Anpec 2012. Disponível em <http://www.anpec.org.br/ encontro_2012.html>. Acesso em janeiro de 2014.

\section{Sobre os autores}

Fagner Diego Spindola Correia Monteiro - fagner.monteiro@caruaru.ifpe.edu.br Instituto Federal de Pernambuco - IFPE, Professor de Economia, Caruaru, Pernambuco.

João Policarpo Rodrigues Lima - jprlima@ufpe.br

Universidade Federal de Pernambuco - UFPE, Professor Titular do Departamento de Economia/PIMES e pesquisador do $\mathrm{CNPq}$, Recife, Pernambuco

\section{Sobre 0 artigo}

Recebido em 30 de abril de 2015. Aprovado em 01 de abril de 2016. 


\section{ANEXO}

Quadro A1 Compatibilização de segmentos industriais de 1990 a 2012

\begin{tabular}{|c|c|c|}
\hline PIA para os anos 1990 e 1995 & $\begin{array}{l}\text { PIA para os anos } 2000 \text { e } 2005 \\
\text { (Classificação usada no trabalho) }\end{array}$ & PIA para os anos 2010 e 2012 \\
\hline $\begin{array}{l}\text { *Produtos alimentares } \\
\text { *Bebidas }\end{array}$ & $\begin{array}{l}15 \text { Fabricação de produtos alimentí- } \\
\text { cios e bebidas }\end{array}$ & $\begin{array}{l}10 \text { Fabricação de produtos alimen- } \\
\text { tícios } \\
11 \text { Fabricação de bebidas }\end{array}$ \\
\hline *Fumo & 16 Fabricação de produtos do fumo & 12 Fabricação de produtos do fumo \\
\hline *Têxtil & 17 Fabricação de produtos têxteis & 13 Fabricação de produtos têxteis \\
\hline $\begin{array}{l}\text { *Vestuário, calçados e artefatos de } \\
\text { tecidos }\end{array}$ & $\begin{array}{l}18 \text { Confecção de artigos do vestuário } \\
\text { e acessórios }\end{array}$ & $\begin{array}{l}14 \text { Confecção de artigos do vestuário } \\
\text { e acessórios }\end{array}$ \\
\hline${ }^{*}$ Couros e peles e produtos similares & $\begin{array}{l}19 \text { Preparação de couros e fabricação } \\
\text { de artefatos de couro, artigos de } \\
\text { viagem e calçados }\end{array}$ & $\begin{array}{l}15 \text { Preparação de couros e fabricação } \\
\text { de artefatos de couro, artigos de } \\
\text { viagem e calçados }\end{array}$ \\
\hline *Madeira & 20 Fabricação de produtos de madeira & 16 Fabricação de produtos de madeira \\
\hline *Papel e papelão & $\begin{array}{l}21 \text { Fabricação de celulose, papel e } \\
\text { produtos de papel }\end{array}$ & $\begin{array}{l}17 \text { Fabricação de celulose, papel e } \\
\text { produtos de papel }\end{array}$ \\
\hline *Editorial e gráfica & $\begin{array}{l}22 \text { Edição, impressão e reprodução de } \\
\text { gravações }\end{array}$ & $\begin{array}{l}18 \text { Impressão e reprodução de } \\
\text { gravações }\end{array}$ \\
\hline *Produtos minerais & $\begin{array}{l}23 \text { Fabricação de produtos coque, } \\
\text { refino de petróleo, elaboração de } \\
\text { combustíveis nucleares e produção } \\
\text { de álcool }\end{array}$ & $\begin{array}{l}19 \text { Fabricação de produtos coque, de } \\
\text { produtos derivados do petróleo e de } \\
\text { biocombustíveis }\end{array}$ \\
\hline $\begin{array}{l}\text { *Química } \\
\text { *Produtos farmacêuticos e } \\
\text { medicinais } \\
\text { * Produtos de perfumaria, sabões } \\
\text { e velas }\end{array}$ & 24 Fabricação de produtos químicos & $\begin{array}{l}20 \text { Fabricação de produtos químicos } \\
21 \text { Fabricação de produtos farmoquí- } \\
\text { micos e farmacêuticos }\end{array}$ \\
\hline $\begin{array}{l}\text { *Borracha } \\
\text { *Produtos de matérias plásticas }\end{array}$ & $\begin{array}{l}25 \text { Fabricação de artigos de borracha } \\
\text { e plástico }\end{array}$ & $\begin{array}{l}22 \text { Fabricação de produtos de borra- } \\
\text { cha e de material plástico }\end{array}$ \\
\hline *Minerais não metálicos & $\begin{array}{l}26 \text { Fabricação de produtos de minerais } \\
\text { não-metálicos }\end{array}$ & $\begin{array}{l}\text { 23 Fabricação de produtos de minerais } \\
\text { não-metálicos }\end{array}$ \\
\hline *Metalúrgica & 27 Metalurgia básica & 24 Metalurgia \\
\hline- & $\begin{array}{l}28 \text { Fabricação de produtos de metal - } \\
\text { exceto máquinas e equipamentos }\end{array}$ & $\begin{array}{l}25 \text { Fabricação de produtos de metal, } \\
\text { exceto máquinas e equipamentos }\end{array}$ \\
\hline *Mecânica & $\begin{array}{l}29 \text { Fabricação de máquinas e } \\
\text { equipamentos }\end{array}$ & $\begin{array}{l}28 \text { Fabricação de máquinas e } \\
\text { equipamentos }\end{array}$ \\
\hline- & $\begin{array}{l}30 \text { Fabricação de máquinas para escri- } \\
\text { tório e equipamentos de informática }\end{array}$ & $\begin{array}{l}26 \text { Fabricação de equipamentos de } \\
\text { informática, produtos eletrônicos e } \\
\text { ópticos }\end{array}$ \\
\hline
\end{tabular}




\begin{tabular}{|c|c|c|}
\hline PIA para os anos 1990 e 1995 & $\begin{array}{l}\text { PIA para os anos } 2000 \text { e } 2005 \\
\text { (Classificação usada no trabalho) }\end{array}$ & PIA para os anos 2010 e 2012 \\
\hline - & $\begin{array}{l}31 \text { Fabricação de máquinas, aparelhos } \\
\text { e materiais elétricos }\end{array}$ & $\begin{array}{l}27 \text { Fabricação de máquinas, aparelhos } \\
\text { e materiais elétricos }\end{array}$ \\
\hline $\begin{array}{l}\text { *Material elétrico e material de } \\
\text { comunicações }\end{array}$ & $\begin{array}{l}32 \text { Fabricação de material elétrico } \\
\text { e de aparelhos e equipamentos de } \\
\text { comunicações }\end{array}$ & - \\
\hline - & $\begin{array}{l}33 \text { Fabricação de equipamentos de } \\
\text { instrumentação médico-hospitalares, } \\
\text { instrumentos de precisão e ópticos, } \\
\text { equipamentos para automação } \\
\text { industrial, cronômetros e relógios }\end{array}$ & - \\
\hline *Material de transporte & $\begin{array}{l}34 \text { Fabricação e montagem de veículos } \\
\text { automotores, reboques e carrocerias }\end{array}$ & $\begin{array}{l}29 \text { Fabricação de veículos automoto- } \\
\text { res, reboques e carrocerias }\end{array}$ \\
\hline - & $\begin{array}{l}35 \text { Fabricação de outros equipamentos } \\
\text { de transporte }\end{array}$ & $\begin{array}{l}30 \text { Fabricação de outros equipamentos } \\
\text { de transporte, exceto veículos } \\
\text { automotores }\end{array}$ \\
\hline $\begin{array}{l}\text { *Mobiliário } \\
\text { *Diversas }\end{array}$ & $\begin{array}{l}36 \text { Fabricação de móveis e indústrias } \\
\text { diversas }\end{array}$ & $\begin{array}{l}31 \text { Fabricação de móveis } \\
32 \text { Fabricação de produtos diversos }\end{array}$ \\
\hline- & 37 Reciclagem & - \\
\hline $\begin{array}{l}\text { Atividades de apoio e de serviços de } \\
\text { caráter industrial } \\
\text { *Atividades administrativas }\end{array}$ & Demais & $\begin{array}{l}33 \text { Manutenção, reparação e instala- } \\
\text { ção de máquinas e equipamentos }\end{array}$ \\
\hline
\end{tabular}

Fonte: Pesquisa Industrial Anual (PIA), IBGE - Elaboração própria.

Quadro A2 Segmentos ganhadores e perdedores: diferença na participação no VTI total: 2012-1990 - nordeste, sudeste e sul

\begin{tabular}{l|r|r|r}
\hline Regiões / Segmentos & Nordeste & Sudeste & Sul \\
\hline Indústrias de transformação & & & \\
\hline Bens não-duráveis de consumo & + & + & - \\
\hline Fabricação de produtos alimentícios e bebidas & + & - & \\
\hline Fabricação de produtos do fumo & - & + \\
\hline Fabricação de produtos têxteis & - & - & - \\
\hline Confecção de artigos do vestuário e acessórios & - & & \\
\hline Preparação de couros e fabricação de artefatos de couro, & & & \\
\hline artigos de viagem e calçados & + & & - \\
\hline Fabricação de produtos de madeira & & + \\
\hline Fabricação de celulose, papel e produtos de papel & - & & + \\
\hline Edição, impressão e reprodução de gravações & + & & + \\
\hline
\end{tabular}




\begin{tabular}{|c|c|c|c|}
\hline Regiões / Segmentos & Nordeste & Sudeste & Sul \\
\hline Bens Intermediários & - & + & + \\
\hline $\begin{array}{l}\text { Fabricação de coque, refino de petróleo, elaboração de combustíveis } \\
\text { nucleares e produção de álcool }\end{array}$ & + & + & + \\
\hline Fabricação de produtos químicos & - & - & - \\
\hline $\begin{array}{l}\text { Produtos farmacêuticos e medicinais / } \\
\text { Fabricação de produtos farmoquímicos e farmacêuticos }\end{array}$ & + & + & + \\
\hline Produtos de perfumaria, sabões e velas & ND & ND & ND \\
\hline Fabricação de artigos de borracha e plástico & + & + & - \\
\hline Fabricação de produtos de minerais não-metálicos & + & + & + \\
\hline Metalurgia básica & - & - & - \\
\hline Fabricação de produtos de metal - exceto máquinas e equipamentos & ND & ND & ND \\
\hline Bens duráveis de consumo e de Capital & + & - & + \\
\hline Fabricação de máquinas e equipamentos & - & - & - \\
\hline Fabricação de máquinas para escritório e equipamentos de informática & ND & ND & ND \\
\hline Fabricação de máquinas, aparelhos e materiais elétricos & ND & ND & ND \\
\hline $\begin{array}{l}\text { Fabricação de material eletrônico e de aparelhos e equipamentos } \\
\text { de comunicações }\end{array}$ & ND & ND & ND \\
\hline $\begin{array}{l}\text { Fabricação de equipamentos de instrumentação médico-hospitalares, } \\
\text { instrumentos de precisão e ópticos, equipamentos para automação } \\
\text { industrial, cronômetros e relógios }\end{array}$ & ND & ND & ND \\
\hline Fabricação e montagem de veículos automotores, reboques e carrocerias & + & + & + \\
\hline Fabricação de outros equipamentos de transporte & ND & ND & ND \\
\hline Outros & + & + & + \\
\hline Fabricação de móveis e indústrias diversas & + & - & + \\
\hline Reciclagem & ND & ND & ND \\
\hline Demais & ND & ND & ND \\
\hline
\end{tabular}

Fonte: Elaboração própria. 
Tabela A1 Comparativo entre países e regiões*: renda per capita no ano do turning point e participação da Indústria no PIB no ano do turning point e em 2010

\begin{tabular}{l|r|r|r|r}
\hline País / Região & Turning Point & $\begin{array}{r}\text { Ano do } \\
\text { no ano do Tur- } \\
\text { ning Point (Em } \\
\text { US\$ de 2005) }\end{array}$ & $\begin{array}{r}\text { Participação da } \\
\text { Indústria no PIB } \\
\text { no ano do } \\
\text { Turning Point }\end{array}$ & $\begin{array}{r}\text { Participação da } \\
\text { Indústria no PIB } \\
\text { no ano de 2010 }\end{array}$ \\
\hline Argentina & 1989 & 4123,76 & 42,35 & 30,90 \\
\hline Brasil & 1985 & 3977,45 & 35,88 & 16,23 \\
\hline Chile & 1988 & 3723,49 & 43,09 & 39,55 \\
\hline Uruguay & 1991 & 4070,93 & 35,55 & 27,50 \\
\hline Sul do Brasil & 1993 & 4646,67 & 37,97 & 20,62 \\
\hline Sudeste do Brasil & 1988 & 5763,76 & 41,89 & 19,13 \\
\hline Nordeste do Brasil & 1989 & 2100,55 & 24,38 & 12,29 \\
\hline Alemanha & $* * 1970$ & 16932,49 & 48,09 & 30,00 \\
\hline Japão & $* * 1970$ & 15161,80 & 43,51 & 27,54 \\
\hline Estados Unidos & $* * 1970$ & 21164,56 & 35,24 & 20,33 \\
\hline Reino Unido & $* * 1970$ & 16837,93 & 42,14 & 20,65 \\
\hline França & 1973 & 19721,47 & 33,05 & 19,60 \\
\hline
\end{tabular}

Fonte: Banco Mundial (2014) e IBGE, Contas Nacionais e Regionais (2013).

* Dados para países desenvolvidos e países da América do Sul oriundos da base de dados do Banco Mundial; dados para Brasil e regiões selecionadas provenientes do IBGE.

** Base de dados do Banco Mundial só dispunha de informações sobre participação da indústria no PIB para os países em questão a partir do ano de 1970. 